\title{
MEDIACIÓN PENITENCIARIA \\ UNA ALTERNATIVA A LA RESOLUCIÓN PACÍFICA DE CONFLICTOS \\ ENTRE INTERNOS
}

PRISON MEDIATION

AS ALTERNATIVE DISPUTE RESOLUTION BETWEEN DOMESTIC PRISONS

\author{
MEDIAÇÃO NA PRISÃO \\ COMO RESOLUÇAO ALTERNATIVA DE CONFLITOS ENTRE AS PRISÕES
}

\author{
Enrique Pastor Seller \\ Elena Huertas Pérez
}

UnIVERSIDAD DE MURCIA, ESPAÑA

RESUMEN: La investigación tiene como objetivo central demostrar la viabilidad de la mediación en el ámbito penitenciario para la resolución alternativa de conflictos interpersonales entre internos. La mediación penitenciaria es un método de resolución pacífica de conflictos entre internos basado en el dialogo y el respeto, permitiendo a las personas implicadas asumir la responsabilidad de su conducta, el protagonismo en el proceso y en la propia resolución pacífica del conflicto. Para ello, en primer lugar, se analizan los mecanismos institucionales y legales de resolución de conflictos interpersonales en los centros penitenciarios españoles. Seguidamente se realiza un análisis comparativo para caracterizar la población penitenciaria, identificando, así mismo, los servicios y/o proyectos de mediación existentes y, por último, se analizan, desde sus participantes, los conflictos y la viabilidad de aplicación de la mediación en el Centro Penitenciario "Murcia I". Para la realización de la investigación se han utilizado fuentes primarias y secundarias, con un carácter tanto cualitativo como cuantitativo. Los resultados de la investigación confirman que la mediación es viable y eficaz en el entorno penitenciario.

PALABRAS CLAVE: mediación; prisión; conflictos; resolución; intervención social.

ABSTRACT: Mediation is a method penitentiary peaceful resolution of internal conflicts based on dialogue and respect, allowing those involved to take responsibility for their behavior, the role in the process 
and the peaceful resolution of the conflict itself. The research center aims to demonstrate the viability of mediation in prisons for the alternative resolution of interpersonal conflicts among inmates. To do so, first, we analyze the institutional and legal mechanisms for resolving interpersonal conflicts in Spanish prisons. It then proceeds to characterize the prison population from a comparative analysis, identifying, likewise, services and / or existing mediation projects and, finally, discusses, from its participants, conflicts and feasibility of using mediation in Specifically a Penitentiary. For the realization of the research have been used primary and secondary sources, with both quantitative and qualitative. The results of the investigation confirm that mediation is feasible and effective in the prison setting.

KEYWORDS: prison; mediation; conflicts; resolution; social intervention.

RESUMO: A mediação é um método penitenciária resolução pacífica de conflitos internos com base no diálogo e no respeito, permitindo que os envolvidos para assumir a responsabilidade por seu comportamento , 0 papel do processo ea resolução pacífica do conflito em si . O centro de pesquisa tem como objetivo demonstrar a viabilidade da mediação nas prisões para a resolução alternativa de conflitos interpessoais entre os presos. Para isso, em primeiro lugar, analisamos os mecanismos institucionais e legais para a resolução de conflitos interpessoais nas prisões espanholas. Ele então começa a caracterizar a população carcerária de uma análise comparativa, identificando, igualmente, serviços e / ou projetos de mediação existentes e, por fim, discute, a partir de seus participantes, os conflitos ea viabilidade do uso da mediação em Especificamente a Penitenciária. Para a realização da pesquisa foram utilizadas fontes primárias e secundárias, sendo que tanto quantitativos como qualitativos. Os resultados da investigação confirmam que a mediação é viável e eficaz no ambiente prisional.

PALAVRAS-CHAVE: prisão; mediaçã; os conflitos; a resolução; intervenção social.

[ 200 ] ENRIQUE PASTOR SELLER Y ELENA HUERTAS PÉREZ 


\section{Introducción}

Los centros penitenciarios son entornos cerrados convivenciales reducidos y "artificiales", donde las personas internas se encuentran sujetas al cumplimiento de normas institucionales de carácter disciplinario y en un marco de relaciones interpersonales mayoritariamente prescritas, lo que en ocasiones genera y cronifica situaciones de fricción y de conflictos entre internos con difícil solución. El ambiente penitenciario caracterizado, entre otros, por un insuficiente espacio vital de intimidad, introspección y reflexión sobre sentimientos y conductas provoca: desconfianzas, dificultad de comunicación, relaciones "perversas" vs. interesadas; sentimientos adversos y conductas defensivas vs. ofensivas conflictivas.

La presente investigación nos acerca a las potencialidades de la mediación como metodología educativa eficaz en el contexto penitenciario, atendiendo a sus valores de aprendizaje interpersonal y a las habilidades sociales que adquieren sus participantes. La mediación penitenciaria es un método de resolución pacífica de conflictos entre internos basado en el dialogo y el respeto. Permite que las personas implicadas asuman la responsabilidad de su conducta, el protagonismo en el proceso y resolución del conflicto y recobren la sensación de paz y de equilibrio emocional existente previa al inicio del conflicto con la ayuda de un profesional "mediador", tercera persona neutral e imparcial que guía el proceso. La mediación penitenciaria permite construir un verdadero espacio para el ejercicio de los derechos de las personas privadas de la libertad para resolver sus conflictos de una manera más democrática y legítima.

De la investigación se constata que la mediación penitenciaria es reciente y escasamente implantada en España, siendo lo más habitual la utilización de las mediadas de régimen disciplinario en la resolución de conflictos entre internos. El estudio empírico que se presenta pretende demostrar que la mediación penitenciaria donde se encuentra implantada resulta ser un método más valioso, desde una perspectiva educativa y sostenible, que la mera aplicación del régimen disciplinario. Así mismo se demuestra, a través del análisis de experiencias, que es un método viable en

\section{Introduction}

Prisons are closed environments discounted convivial and "artificial", where the inmates are subject to compliance with institutional disciplinary and interpersonal relations framework prescribed majority, which sometimes creates friction situations and internal conflicts intractable. The prison environment characterized, among others, by insufficient living space of intimacy, introspection and reflection on feelings and behaviors cause: mistrust, communication difficulties, relationships "perverse" vs. concerned; adverse feelings and behaviors vs. defensive. Offensive conflicting.

This research brings us closer to the potential of mediation as an effective educational methodology in prison, according to their values and interpersonal learning social skills that participants acquire. Mediation is a method of peaceful conflict resolution based on dialogue and respect, adequate for use in a penitentiary context. It allows those involved to take responsibility for their behavior, the protagonist in the conflict resolution process, and regain a sense of peace and emotional balance existing prior to the start of the conflict with the help of a professional "mediator" neutral third party and impartial guide the process. Mediation allows building a real prison space for the exercise of the rights of persons deprived of freedom to resolve their conflicts in a more democratic and legitimate way?.

The investigation found out that prison is recent mediation and rare operation in Spain, the most common being the use of disciplinary mediated in resolving internal conflicts. The empirical study presented aims to demonstrate that mediation prison where implanted it be a more valuable, from an educational perspective and sustainable, that application of the disciplinary system. Furthermore it is shown, through the analysis of experiences, it is a viable method in the prison for the alternative resolution of interpersonal conflicts between detainees and highly satisfactory by participants, representing a potential for transfer in centers where there is implanted. The empirical study therefore aims to demonstrate the benefits of the implementation of mediation in prisons and its viability in the alternative and peace- 
el ámbito penitenciario para la resolución alternativa de conflictos interpersonales entre las personas privadas de libertad y altamente satisfactorio por sus participantes, lo que supone una potencialidad para su transferencia en los centros en donde no se encuentra implantada. El estudio empírico pretende, por consiguiente, demostrar los beneficios que aporta la implantación de la mediación en el ámbito penitenciario y su viabilidad en la resolución alternativa y pacífica de conflictos interpersonales entre las personas privadas de libertad.

Desde sus orígenes, el sistema penitenciario se ha presentado como una agencia de resocialización, pero la contundencia de los hechos habla por sí sola: el centro penitenciario esta lejos de haber alcanzado su objetivo. Podemos señalar, con Foucault (1990), que es hora de levantar el acta del fracaso del proyecto penitenciario. La prisión surgida con la intención de "reformar" al sujeto delincuente ha logrado todo lo contrario, lo que obliga a interrogarse acerca de la función que cumple el sistema penitenciario en las sociedades modernas. Todo indica que la prisión moderna funciona más como un dispositivo de control social y represión que como dispositivo reeducador y reintegrador. La institución penitenciaria no deja de ser una estructura disciplinaria agobiante y exhaustiva (Marcuello y García, 2011), Foucault (1990) lo identificaba con el cumplimiento de penas en "arquitecturas masivas", en las que se produce una "democratización" de los castigos infligidos. Según el reglamento penitenciario una de las finalidades de aplicación del régimen disciplinario es la estimulación de la responsabilidad en los internos que cometen una falta, pero, por el contrario, tiende a fomentar la "irresponsabilidad" de los internos al aplicarse, en muchos casos, la sanción sin relación ninguna a la falta y sin arrepentimiento por parte de las partes.

\section{Metodología y proceso de investigación}

La investigación, cuyos principales resultados y conclusiones se presentan en éste artículo, pretende demostrar la viabilidad de la mediación en el ámbito penitenciario para la resolución alternativa de conflictos interpersonales entre internos; siendo esta hipótesis la que focaliza y orienta la investigación. Para ful resolution of interpersonal conflicts among the detainees.

Since its inception, the prison system has been presented as an agency of rehabilitation, but the weight of events speaks for itself: the prison is far from reaching its goal. We note, with Foucault (1975, 1990), it is time to take the minutes of the prison project failure. The prison emerged with the intention of "reforming" the subject offender has the opposite, forcing us to question the role of the prison system in modern societies. It appears that the modern prison functions more as a device of social control and repression as re educator and reintegrative device. The penitentiary is no longer an exhausting and exhaustive disciplinary structure (Marcuello \& García, 2011), Foucault (1990) identified him with the serving of sentences in "massive architectures", in which there is a "democratization" of punishment - inflicted. Prison regulations one of the purposes of application of the disciplinary regime is stimulation of liability inmates who commit a foul, but, on the contrary, tends to encourage the "irresponsibility" of inmates to apply, in most cases, no punishment without regard to fault and without repentance on the part of the parties.

\section{Methodology and research process}

The research, the main results and conclusions presented in this article aims to demonstrate the viability of mediation in prisons for the alternative resolution of interpersonal conflicts between inmates; this hypothesis being that focuses and directs the research. For proper

[ 202 ] ENRIQUE PASTOR SELLER Y ELENA HUERTAS PÉREZ 
su adecuada contrastación nos planteamos, de manera secuencial, los siguientes objetivos:

- Analizar los mecanismos institucionales y legales de resolución de conflictos interpersonales en los centros penitenciarios españoles.

- Caracterizar la población penitenciaria española.

- Identificar y describir los servicios y/o proyectos de mediación existentes en los Centros Penitenciarios de España.

- Analizar, desde sus participantes, los conflictos y la viabilidad de aplicación de la mediación en un Centro Penitenciario.

Atendiendo a estos objetivos, el proceso de acercamiento al objeto de estudio se ha secuenciado en tres fases.

Fase 1: Describir y analizar los principales referentes teóricos y normativos penitenciarios en España, respecto de las modalidades en la aplicación de sanciones en dicho medio.

Fase 2: Identificar y conocer los centros penitenciarios que disponen de servicio y /o proyecto de mediación y la caracterización del mismo.

Las dimensiones de análisis utilizadas han sido: profesionales implicados; antigüedad del servicio/proyecto; metodología de mediación empleada y resultados obtenidos. En esta fase se aplican fuentes secundarias (informes y memorias de Asociaciones de Mediación penitenciaria) y primarias, a través de entrevistas estructuradas a actores claves estratégicos en los centros penitenciarios y en razón de los objetivos diferenciados que orientan el estudio:

- Técnicos de la Unidad de Apoyo del Ministerio del Interior, con el objetivo de identificar, localizar y conocer los centros penitenciarios que disponen de servicio y/o proyectos de mediación y su perfil básico en España.

- Responsables de los centros penitenciarios que utilizan mediación penitenciaria en España con la finalidad de caracterizar los servicios y/o proyectos de mediación y, por último,

- Profesionales de las asociaciones de mediación penitenciaria que prestan servicios de mediación en los centros penitenciarios de España. contrasting we consider, in sequence, the following objectives:

- Analyze the legal and institutional mechanisms for resolving interpersonal conflicts in Spanish prisons.

- Characterize the Spanish prison population. - Identify and describe the services and / or existing mediation projects in the prisons of Spain. - Analyze, from the participants point of view, conflicts and feasibility of using mediation in a Penitentiary.

Based on these objectives, the process of approaching the object of study has been sequenced in three phases.

Phase 1: Describe and analyze the main theoretical and policy concerning prisons in Spain, on modalities for the application of sanctions in that medium.

Phase 2: Identify and know the prisons that have service and / or mediation project and characterization.

The dimensions of analysis used were: professionals involved, length of service / project mediation methodology used and results obtained. At this stage apply secondary sources (reports and memoirs of prison Mediation Associations) and primary, through structured interviews with strategic stakeholders in prison and because of the different objectives that guide the study:

- Technical Support Unit of the Ministry of the Interior, with the goal of identifying, locating and know that prisons have service and / or mediation projects and basic profile in Spain.

- Responsible for prisons using mediation prison in Spain in order to characterize the services and / or mediation projects and, finally,

- Professional associations serving prison mediation in prisons in Spain.

Phase 3: comprehensive analysis of the case, namely the Prison Murcia l, in order to learn from his actors the validity of mediation in resolving conflicts in a particular school which is not implemented. 
Fase 3: análisis exhaustivo de caso, concretamente del Centro Penitenciario Murcia l, con el fin de conocer desde sus actores la validez de la mediación en la resolución de conflictos en un centro concreto donde no se encuentra implementada.

Para la obtención de datos se han empleado diferentes técnicas atendiendo a los sujetos de investigación y objeto. Se realizaron entrevistas a la tipología de actores de los centros penitenciarios, siendo, a su vez los potenciales beneficiarios y protagonistas de la mediación, concretamente a: equipo directivo, profesionales e internos del Centro. En el primer caso, se orientaron a disponer de datos sociodemográficos, estadísticos y tipología de conflictos de la población penitenciaria. Por otra, se realizaron entrevistas semiestructuradas mediante cuestionario y preguntas abiertas a las personas profesionales e internas del Centro Penitenciario con el fin de conocer los conflictos que surgen en el centro, la frecuencia y el método de resolución, la efectividad de los métodos que se utilizan y, por el último, el conocimiento y la aceptación de la mediación identificando, así mismo, los conflictos que consideran son objeto de mediación. En este caso, el muestreo es no probabilístico aleatorio, atendiendo a un procedimiento de selección informal/bola de nieve y partiendo de la voluntariedad de los encuestados que previamente acreditan por escrito aceptar participar.

Los sujetos que han participado en ésta última fase han sido 78 (profesionales e internos), siendo el $56 \%$ internos y el $47,44 \%$ profesionales del centro en sus diferentes categorías (seguridad, equipo técnico y superior técnico, sanitario, administrativo y directivo). En cuanto a la experiencia de los sujetos el $33,33 \%$ de los participantes están en el Centro hace menos de un año, el 36,92\% 10 o más de 10 años y el 35\% desde 1 a 6 años.

Como se ha señalado anteriormente y para dotar a la investigación de la máxima validez y fiabilidad, en el proceso de obtención de datos se han empleado/combinado diferentes técnicas desde una estrategia de lógica triangular con el fin de revelar diferentes aspectos de la realidad empírica (Denzin, 1975, Cea D'Ancona, 1998, Perello, 2010): concretamente: análisis documental, entrevistas y cuestionario. Por otra parte, en cuanto al ámbito
For data collection has used different techniques according to the subjects of research and object. Interviews were conducted with the type of players in the prisons, being, in turn potential beneficiaries and protagonists of mediation, namely: management, professionals and interns of the Center. In the first case, we have focused on sociodemographic data, statistical and type of conflict in the prison population. In addition, semistructured interviews were conducted by questionnaire and open questions to professional people and internal Correctional Center to find the conflicts that arise in the center, the frequency and method of resolution, the effectiveness of the methods used and, last, the knowledge and acceptance of mediation identifying, likewise, consider the conflicts that are the subject of mediation. In this case, the non-probability sampling is random, based on a selection procedure informal / snowball and basis of voluntary respondents credited prior written consent to participate.

Subjects who have participated in this last phase were 78 (professional and domestic), being $56 \%$ and $47.44 \%$ internal center professionals in different categories (safety, technical equipment and superior technical, health, administrative and managerial). As for the subjects experience $33.33 \%$ of the participants are in the center less than a year, 10 or $36.92 \%$ more than 10 years and $35 \%$ from 1-6 years.

As noted above and to provide a high research validity and reliability, the data collection process has been used / combined different techniques from a triangular logic strategy to disclose various aspects of empirical reality (Alvarez-Uria \& Varella, 2009; Cea D’Ancona, 1998; Denzin, 1975; Perello, 2010): namely: document analysis, interviews and questionnaire. Moreover, as to the temporal scope, this is a side cross-sectional study combining macrosociological (universe of mediation centers in the context state prison) and microsociological through unique case study in a concrete prison intensive approach allows the same internal and professionals. A mixed research, quantitative aspects obtained while and be quantified objectives, such as: number of sites that use mediation in Spain, participating entities, frequently producing conflicts, etc., And qualitative, mean-

[ 204 ] ENRIQUE PASTOR SELLER Y ELENA HUERTAS PÉREZ 
temporal, se trata de un estudio transversal combinando la vertiente macrosociológica (universo de centros con servicios de mediación penitenciaria en el contexto estatal) y microsociológico, a través del estudio del caso singular en un centro penitenciario concreto que permite un acercamiento intensivo a los internos y profesionales del mismo. Una investigación mixta, cuantitativa, en tanto obtiene aspectos objetivos y susceptibles de cuantificación, tales como: numero de Centros que utilizan mediación en España, entidades participantes, frecuencia en que producen los conflictos, etc., y cualitativa, en tanto, identifica cómo se desarrolla la mediación, metodología utilizada y, desde el análisis de caso, analizar los conflictos que surgen, frecuencia, método de resolución, efectividad de las medidas penitenciarias en la resolución de conflictos, conocimiento de la mediación por los participantes, su posible aceptación y los conflictos que consideran serían objeto de la mediación.

Respecto a los instrumentos de obtención de datos, concretamente el cuestionario con preguntas abiertas es de elaboración propia y se ha validado de manera previa y efectiva para cumplir los objetivos propuestos. El cuestionario recoge datos cuantitativos y cualitativos, compuesto por un total de 29 cuestiones, combina preguntas abiertas y cerradas, lo que nos permite concretar y sistematizar respuestas $y$, a la vez, conseguir una mayor participación y acercamiento al objeto de estudio. El cuestionario dispone de una breve introducción del estudio, perfil de participantes, características del cuestionario y notas aclaratorias y ha superado de manera satisfactoria el pretest, a través del cual se han podido introducir algunas mejoras orientadas a aclaraciones terminológicas/conceptuales y el "cierre"descriptores. Para el análisis univariable y bivariable se ha utilizado el programa informático SPSS 15.0 (Statistical Package for the Social Science) ilustrando sus datos con gráficas (barras y sectores) con la intención de visualizar mejor los datos obtenidos.

\section{Resultados de la investigación}

Los resultados de la investigación se presentan en razón de los objetivos y dimensiones de análisis anteriormente mencionados. while, identifies how develops mediation methodology and from the case study, analyze the conflicts that arise, often solving method, effectiveness of correctional measures in conflict resolution, mediation knowledge of the participants, and possible acceptance conflicts they consider would be subject to mediation.

Regarding the data collection instruments, namely the structured questionnaire is homemade and validated prior to and effective to meet the objectives. The questionnaire includes quantitative and qualitative data, consisting of a total of 29 questions, combining open and closed questions, allowing us to define and systematize responses and, in turn, achieve greater participation and approach the object of study. The questionnaire is a brief introduction of the study, participants profile, characteristics of the questionnaire and explanatory and has successfully passed the pretest, through which some improvements have been oriented terminological clarifications / conceptual and the "closing" descriptors. For univariates and bivariate been used SPSS 15.0 (Statistical Package for Social Science) graphs illustrating their data (Bar \& Pie) with the intention to better visualize the data.

\section{Results of the investigation}

The results of the investigation are presented in view of objectives and analysis dimensions mentioned above. 


\subsection{Análisis de los mecanismos institucionales y legales de resolución de conflictos interperso- nales en los centros penitenciarios españoles}

Desde la perspectiva de la Criminología y de las Ciencias Sociales, la pena de prisión no se justifica por las funciones de custodia y castigo, sino por el fin rehabilitador. La propia Constitución Española señala en el Art. 25.2 que "las penas privativas de libertad y las medidas de seguridad estarán orientadas hacia la reeducación y reinserción social y no podrán consistir en trabajos forzados". De igual forma, la legislación específica, concretamente la Ley Orgánica General Penitenciaria, en su Art. 1 establece que "las instituciones Penitenciarias reguladas en la siguiente ley tienen como fin primordial la reeducación y la reinserción social de los sentenciados a penas y medidas penales privativas de libertad; así como la retención y custodia de detenidos, presos y penados". Esta ley no sólo creó el marco jurídico capaz de sostener la realización del tratamiento en prisión, sino que dotó, para su ejecución, de trabajadores de las ciencias sociales. Específicamente, la ley 39/70 sobre reestructuración de los Cuerpos Penitenciarios, creó el Cuerpo Técnico de Instituciones Penitenciarias. En su Art. 2.1 determina que los funcionarios de dicho cuerpo realizarán las funciones propias de su especialidad en materia de observación, clasificación y tratamiento de los internos, así como las de dirección e inspección de las Instituciones y Servicios.

La legislación penitenciaria establece medidas disciplinarias orientadas a solucionar y reducir los conflictos interpersonales, a través de un sistema gradual de sanciones de obtención de beneficios y de perdida de los mismos. El régimen disciplinario está dirigido a garantizar la seguridad, el buen orden y la convivencia ordenada para estimular el sentido de la responsabilidad y la capacidad de autocontrol de las personas dentro del centro penitenciario (Art. 231 RP 190/1996). Previene algunas conductas violentas debido a la intimidación que supone el sometimiento a un proceso y la aplicación de una sanción que, además de sus efectos aflictivos, genera una serie de consecuencias negativas colaterales (pérdida de permisos y dificultad para progresar de grado, entre otros aspectos). Este método puede reducir algún conflicto, puede hacer que las partes lo oculten, pero al tener su fundamento en

\subsection{Analysis of the legal and institutional me- chanisms for resolving interpersonal conflicts in Spanish prisons}

From the perspective of Criminology and Social Sciences, the prison sentence is not justified by the functions of custody and punishment, but rehabilitation order. The Spanish Constitution states in Article 25.2 that "imprisonment and security measures which are aimed at the rehabilitation and social reintegration and may not involve forced labor." Similarly, specific legislation, namely the General Penitentiary Law, in Article 1 states that "penal institutions regulated by the following law has as its main goal the rehabilitation and social reintegration of those sentenced to custodial sentences and penal measures of freedom, and the retention and custody of detainees, prisoners and convicts. "This law not only created the legal framework to support the delivery of treatment in prison, but gave, for execution of social science workers. Specifically, the law 39/70 Restructuring Corrections Corps, created the Technical Corrections. In its Article 2.1 determines that said board officials perform the functions of his specialty in observation, classification and treatment of prisoners and the management and inspection of the institutions and services.

The law establishes prison disciplinary measures aimed at solving and reduce interpersonal conflicts and reduce, through a gradual system of sanctions of profit and loss thereof. The disciplinary system is intended to ensure the security, good order and orderly coexistence to stimulate the sense of responsibility and self-control of those within the prison (Art. 231 RP 190/1996). Prevents some violent behavior because of intimidation involved submitting to a process and the application of a penalty, in addition to its distressing effects, generates a number of negative side effects (loss of permits and difficulty grade progress, among other things). This method can reduce any conflict, the parties can hide it, but to have its basis in an exclusively negative reaction does not generate positive learning and in most cases the conflict is not resolved, the study will reinforce this conclusion.

[ 206 ] ENRIQUE PASTOR SELLER Y ELENA HUERTAS PÉREZ 
una reacción exclusivamente negativa, no genera aprendizajes positivos y en la mayoría de los casos el conflicto no se soluciona.

Las faltas están recogidas en el Art. 108 del Reglamento Penitenciario aprobado por el Real Decreto 1201/1981 de 8 de mayo y las sanciones, que podrán imponerse en relación a la falta cometida, en el Art. 233 del Reglamento penitenciario, por el Real Decreto 190/1996 de 9 de febrero. Las faltas se clasifican en muy graves, graves y leves. Según este Decreto los insultos, las agresiones y el robo de materiales a otros internos son conflictos catalogados como faltas y el método de resolución de conflictos utilizado en el Centro es la sanción que corresponda, según el Reglamento Penitenciario. Los internos son corregidos disciplinariamente en los casos establecidos en el Reglamento Interno y con las sanciones previstas en el capítulo IV Régimen Disciplinario en la Ley Orgánica 1/1979, de septiembre, General Penitenciaria y en el Titulo X Del Régimen disciplinario y las recompensas en el Reglamento Interno. El régimen disciplinario se aplicará a todos los internos, con la excepción en el Art. $188.4^{\top}$ del Reglamento, con independencia de su situación procesal y penitenciaria tanto en los Centros penitenciarios como durante los traslados, conducciones o salidas autorizadas.

Por su parte, las sanciones se clasifican en muy graves, graves y leves siguiendo el Art. 233 Decreto 190/1996 de 9 de febrero del Reglamento Penitenciario. Todas las sanciones impuestas según el reglamento interno penitenciario son de perdida de beneficios y aislamiento de internos. En un contexto en que una persona se encuentra aislada socialmente, las sanciones son de aislamiento también y de perdida de libertad. El tiempo máximo de resolución de una sanción es de 3 meses, sino se archiva el conflicto.

El Reglamento Penitenciario no ofrece cobertura específica y explícita al proceso de la mediación, pero ello no impide su aplicación siempre que se respeten las normas procedimentales del régimen disciplinario para respetar escrupulosamente el principio de legalidad. En este sentido, es posible aplicar la mediación atendiendo a los artículos siguientes:

- Si la sanción es de aislamiento (Art. 43.2 LOGP).

El Art. 255 RP prevé la suspensión de la efectividad de las sanciones de aislamiento impuestas:
Faults are contained in Article 108 of the Prison Regulations approved by Royal Decree 1201/1981 of 8 May and penalties that may be imposed in relation to the offense committed, in Article 233 of the Prison Rules, by Royal Decree 190/1996 of 9 February. The faults are classified as very serious, serious and minor. According to this decree the insults, assaults and theft of materials other inmates are classified as misdemeanors conflict and conflict resolution method used in the center is the corresponding penalty, prison regulations. Inmates are corrected in disciplinary cases provided for in the Rules of Procedure and the penalties provided in Chapter IV Disciplinary Organic Law 1/1979, September, General Penitentiary and Part $X$ of the disciplinary and rewards in the Rules. The disciplinary system applies to all inmates, except in Article 188.4 of the Regulations, regardless of their legal situation and prison both in prisons and during transfers, conduits or authorized outlets.

Meanwhile, sanctions are classified as very serious, serious and minor, according to Art 233 Decree 190/1996 of 9 February the Prison Rules. All sanctions imposed by prison rules are lost profits and internal isolation. In a context in which a person is socially isolated, sanctions are also isolation and loss of freedom. The maximum resolution of a penalty is 3 months, but the conflict is filed.

The Prison Rules provides no specific and explicit coverage of the mediation process, but this does not prevent the application provided that the procedural rules of the disciplinary regime to keep strictly to the principle of legality. In this sense, mediation can be applied taking into account the following items:

- If the punishment is isolation (Art. 43.2 LOGP). The RP Section 255 provides for the suspension of the effectiveness of sanctions imposed isolation: this suspension shall be ex officio or at the proposal of the Board of Treatment "when circumstances warrant" (Art. 255.1 RP).

- If isolation is not punishment (Art. 42.6 LOGP): "Reduction of penalty and cancellation periods served the purpose of rehabilitation and social reintegration" by a decision of the disciplinary committee, ex officio or at the proposal of the Board of Treatment. This reduction could be 
esta suspensión será de oficio o a propuesta de la Junta de Tratamiento "cuando las circunstancias lo aconsejen" (Art. 255.1 RP).

- Si no es sanción de aislamiento (Art. 42.6 LOGP): "Reducción de la sanción y de los plazos de cancelación atendidos los fines de reeducación y reinserción social" por decisión motivada de la comisión disciplinaria, de oficio o a propuesta de la Junta de Tratamiento. Esta reducción podría quedar centrada en la sanción de amonestación y derivarse hacia los acuerdos de las partes. Ambas interpretaciones caen dentro de la norma constitucional (Art. 25.12 CE y el Art. 1 LOGP).

Sería posible suspender el procedimiento, el Director sería competente para iniciar o no el procedimiento disciplinario en función de los acuerdos derivados del procedimiento de mediación e incluso, según casos, revocar la sanción y anular la incompatibilidad si el resultado de la mediación es un acuerdo. (Art. 256 R.P 190/1996)

En general, solo se habla en derecho de sanciones negativas, pero éste debe estimular acciones innovadoras, como la reparación del autor a la victima, haciendo algo en favor de la misma o la sociedad. Hay que estimular actos innovadores, a nivel preventivo fomentar todo tipo de actividades que promuevan el bienestar en los Centros para que se reduzca la posibilidad de que surjan conflictos. Esta estimulación de actos socialmente útiles puede realizarse a través de la mediación penitenciaria, en lugar de la represión con la aplicación de la pena tradicional: castigo-retributivo. Desde una perspectiva psicosocial la intervención orientada a la adquisición y mantenimiento de conductas y la reducción o eliminación de conductas se basa en técnicas basadas, fundamentalmente, en cuatro principios operantes básicos: reforzamiento positivo, reforzamiento negativo, castigo positivo y castigo negativo. Las sanciones de "aislamiento" y "pérdida de beneficios" corresponden a técnicas operantes para reducir o eliminar conductas que denominadas "tiempo fuera" y "coste de respuesta", y se basan en el principio del castigo negativo. La sanción "pérdida de beneficios" se utiliza para las faltas leves y algunas graves. La sanción de "aislamiento" es la utilizada en algunas faltas graves y en las muy graves. centered on the penalty of reprimand and resulting into agreements of the parties. Both interpretations are within the constitutional provision (Art. 25.12 EC and Article 1 LOGP).

It would be possible to stay the proceedings, the Director would be competent to initiate disciplinary proceedings or not depending on the agreements resulting from mediation procedure and even, cases, revoke and annul the sanction incompatibility if the outcome of the mediation is an agreement. (Art. 256 R.P 190/1996)

In general, only spoken in right of negative sanctions, but this should stimulate innovative activities, such as repair of the author to the victim, doing something for the same or society. Innovative actions should be encouraged to promote preventive level, or activities that promote wellness centers to reduce the possibility of conflicts. This stimulation can be socially useful acts through mediation prison, instead of repression with the penalty Traditional-retributive punishment. From a psychosocial intervention aimed at the acquisition and maintenance of behavior and the reduction or elimination of behaviors is based on techniques based supported mainly on four basic operant principles: positive reinforcement, negative reinforcement, positive punishment and negative punishment. Sanctions "isolation" and "lost profits" are operant techniques to reduce or eliminate behaviors that called "time out" and "response cost" and are based on the principle of negative punishment. The sanction "lost profits" is used for minor offenses and some serious. The sanction of "isolation" is used in some serious faults and the very serious. 


\subsection{Caracterización y análisis comparativo de la población penitenciaria española}

España cuenta, después de Reino Unido, con la tasa más elevada de población reclusa de Europa, con 154 reclusos por cada 100.000 habitantes.

\subsection{Characterization and comparative analysis of the Spanish prison population}

Spain has, after the UK, with the highest rate of prison population of Europe, with 154 prisoners per 100,000 inhabitants.

Gráfico 1. Tasa de población reclusa por cada 100.000 habitantes en varios países europeos

Figure 1. Imprisonment rate per 100,000 inhabitants in several European countries

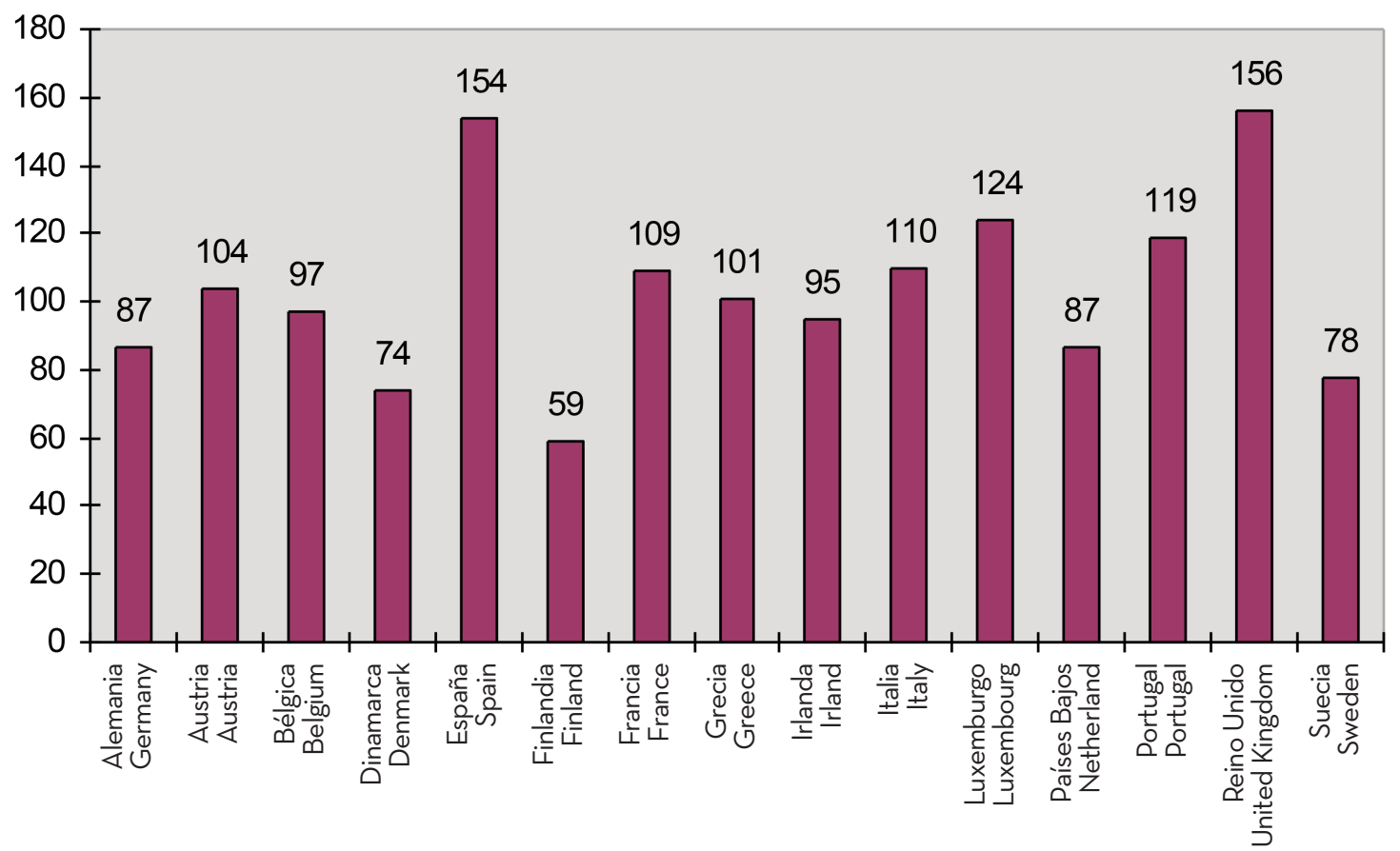

Fuente: Elaboración propia a partir de datos de Internacional Center for Prisión Studies. (Datos de 2011, excepto Austria, Bélgica, Grecia y Suecia que son de 2010).

Source: Compiled from data International Center for Prison Studies. (Data from 2011, except Austria, Belgium, Greece and Sweden are 2010).

Del análisis de los datos estadísticos oficiales del Ministerio del Interior, desde 2009 hasta 2011 se ha producido un descenso en 2.364 internos. A pesar de este descenso considerable en los últimos 3 años, el número de internos se ha duplicado desde 1990. Dos de los factores que explican este hecho son las reformas del Código Penal y en especial el incremento de la penalización de los delitos de violencia de género y los relativos a la seguridad vial.

Según datos del Ministerio de Interior el perfil mayoritario de la población penitenciaria está representado por personas que han vivido en ambientes deprimidos, tienen escasa formación y no disponen de cualificación profesional ni habilidades sociales. En este sentido, la asociación foucaultiana entre delitos contra la propiedad y determinados sectores de la población más vulnerable sigue siendo una reali-
An analysis of the official statistics of the Ministry of the Interior, from 2009 to 2011 there has been a decrease in internal 2364. Despite this significant decline in the last three years, the number of inmates has doubled since 1990. Two of the factors behind this are the reforms of the Penal Code and in particular the increase of crimes of gender violence and road safety. 1

According to the Ministry of Interior the majority of the population profile is represented by people who have lived in depressed environments, who have low education and do not have professional skills or social skills. Thus, the association between crime and certain sectors of the population most vulnerable remains a social reality consists - table, as well as show our data and other works and authors (Alvaro, 2007; Azaola \& 
dad social constatable, como así lo muestran nuestros datos y otros trabajos y autores (Álvaro, 2007; Azaola y Bergman, 2007, Marcuello y García, 2011). Un porcentaje significativo de estas personas son analfabetas funcionales y otro grupo relevante no tiene estudios de educación primaria o no los ha completado. Existe un alto número de reclusos extranjeros y un alto porcentaje de drogodependientes (en 2009, un $25,6 \%$ de la población penitenciaria estaba diagnosticada con patologías psiquiátricas).

Desde una perspectiva de género, constatamos un fuerte incremento de mujeres internas en los últimos años, siendo el 7,6\% de la población. Los países europeos tienen un promedio de población reclusa femenina entre el $4 \%$ y el $6 \%$, excepto Portugal, que supera a España con una tasa de casi el 10\%. Este hecho se debe, entre otras, al gran número de mujeres extranjeras que cumplen condenas largas por tráfico de estupefacientes. En cuanto a la edad, el grupo más representativo es el de personas que tienen entre 31 y 40 años, alcanzando el 34,60\%.

Respecto a la tipología de los delitos (según tipifica el Código Penal), en el caso de los hombres los delitos mayoritarios siguen siendo "contra el patrimonio y el orden socioeconómico" vinculados a la propiedad (robos) con el 39,70\% del total de hombres y en el caso de las mujeres son los "delitos contra la salud pública" (tráfico de drogas) con el 47,56\% del total de mujeres.

\subsection{Identificación, descripción, caracterización y metodología de los servicios y/o proyectos de mediación existentes en los Centros Penitencia- rios de España}

La mediación penitenciaria se viene desarrollando en los Centros penitenciarios españoles desde 2005 a raíz de la experiencia en el Centro Penitenciario de Madrid III con la iniciativa, entre otros, de J. C. Ríos (2001, 2008 et.al. 2005) Se realiza mediante un programa específico de intervención denominado Servicio Permanente de Resolución Dialogada de Conflictos orientado a la prevención de conflictos en el centro, a través de ambientes relajados y acogedores orientados a promover una estancia lo más pacifica posible, utilizando habilidades de resolución de conflictos (prevención) y en caso de surgir éste intentando solucionarlo con la ayuda de un mediador. La finalidad de este programa es que
Bergman, 2007, Marcuello \& García, 2011). A significant percentage of these people are functionally illiterate and another group has no relevant primary studies completed or not. There is a high number of foreign prisoners and a high percentage of drug addicts (in 2009, $25.6 \%$ of the prison population is diagnosed with tobacco $\cdot$ psychiatric disorders).

From a gender perspective, we find a strong increase in female inmates in recent years, with $7.6 \%$ of the population. European countries have an average female prison population between $4 \%$ and $6 \%$, except Portugal, Spain beats at a rate of almost $10 \%$. This is due, among others, the large number of foreign women who meet long count of drug trafficking.

In terms of age, is the most representative group of people between 31 and 40 years, reaching $34.60 \%$.

Regarding the type of crime (as typifies the Criminal Code), in the case of men remain major crimes "against equity and socio-economic order" related to pro - piety (theft) with $39.70 \%$ of all men and for women are the "crimes against public" (drug trafficking) with $47.56 \%$ of all women.

\subsection{Identification, description, characterization and methodology of the services and / or exis- ting mediation projects in the prisons of Spain}

Mediation prison is being developed in Spanish prisons since 2005 as a result of the experience in the prison of Madrid III with the initiative, among others, J. C. Rivers (2001, 2008 et al 2005) was performed using a specific intervention program called "Permanent Service for Conflict Resolution" through dialogue aimed at conflict prevention in the center, through relaxed and welcoming environment designed to promote stay as peacefully as possible, using conflict resolution skills (prevention) and in case there is trying to solve with the help of a mediator. The purpose of this program is for inmates

[ 210 ] ENRIQUE PASTOR SELLER Y ELENA HUERTAS PÉREZ 
los internos e internas resuelvan sus conflictos pacíficamente con la ayuda de un mediador.

La convivencia en los centros penitenciarios genera un importante número de conflictos interpersonales y la menor parte de ellos desembocan en actos antidisciplinarios. En ocasiones la imposición de sanciones sin embargo no llega a resolver el problema personal y este se queda enquistado.

En España existen 80 Centros Penitenciarios, aunque, según datos de la Secretaria General de Instituciones Penitenciarias, el servicio de mediación únicamente se ha implantado en 14 Centros, concretamente: A lama, Orense, Madrid III, Madrid IV, Alicante, Villena, Valencia, Almería, Granada, Málaga, Las Palmas, Tenerife, León, y Alcázar de San Juan. Contrastando estos datos con los procedentes de asociaciones vinculadas con el entorno penitenciario, debemos añadir a los anteriores 4 centros, Zuera, Daroca, Araba/Álava y Pamplona, por lo que podemos concluir que son 18 los Centros penitenciarios que utilizan servicios mediación propios y/o a través de asociaciones en España. El siguiente Mapa detalla con exactitud la ubicación de los centros penitenciarios que tienen implantado un servicio de mediación. solve their conflicts peacefully with the help of a mediator.

Coexistence in prisons generate considerable interpersonal conflict and less of them lead to acts. Sometimes sanctions but fails to solve the personal problem and this remains entrenched.

In Spain there are 80 prisons, although, according to the Secretary General of Prisons, the mediation service has been implemented only in 14 centers, including: A lama, Orense, Madrid III, IV Madrid, Alicante, Villena, Valencia, Almería, Granada, Malaga, Las Palmas, Tenerife, Leon and Alcazar de San Juan. Contrasting these data with those from associations connected with the prison environment, we must add to the above 4 centers, Zuera, Daroca, Araba / Álava and Pamplona, so we can conclude that there are 18 prisons that use mediation services themselves and / or through associations in Spain.

The service is provided by prison staff both directly and through NGOs and university departments, correctional professionals being mainly those carrying out the project: "educators trained mediation and conflict resolution".

Mapa 1. Centros Penitenciarios que disponen de servicio de mediación

Map 1. The map below details the exact location of prisons that have implemented a mediation service.

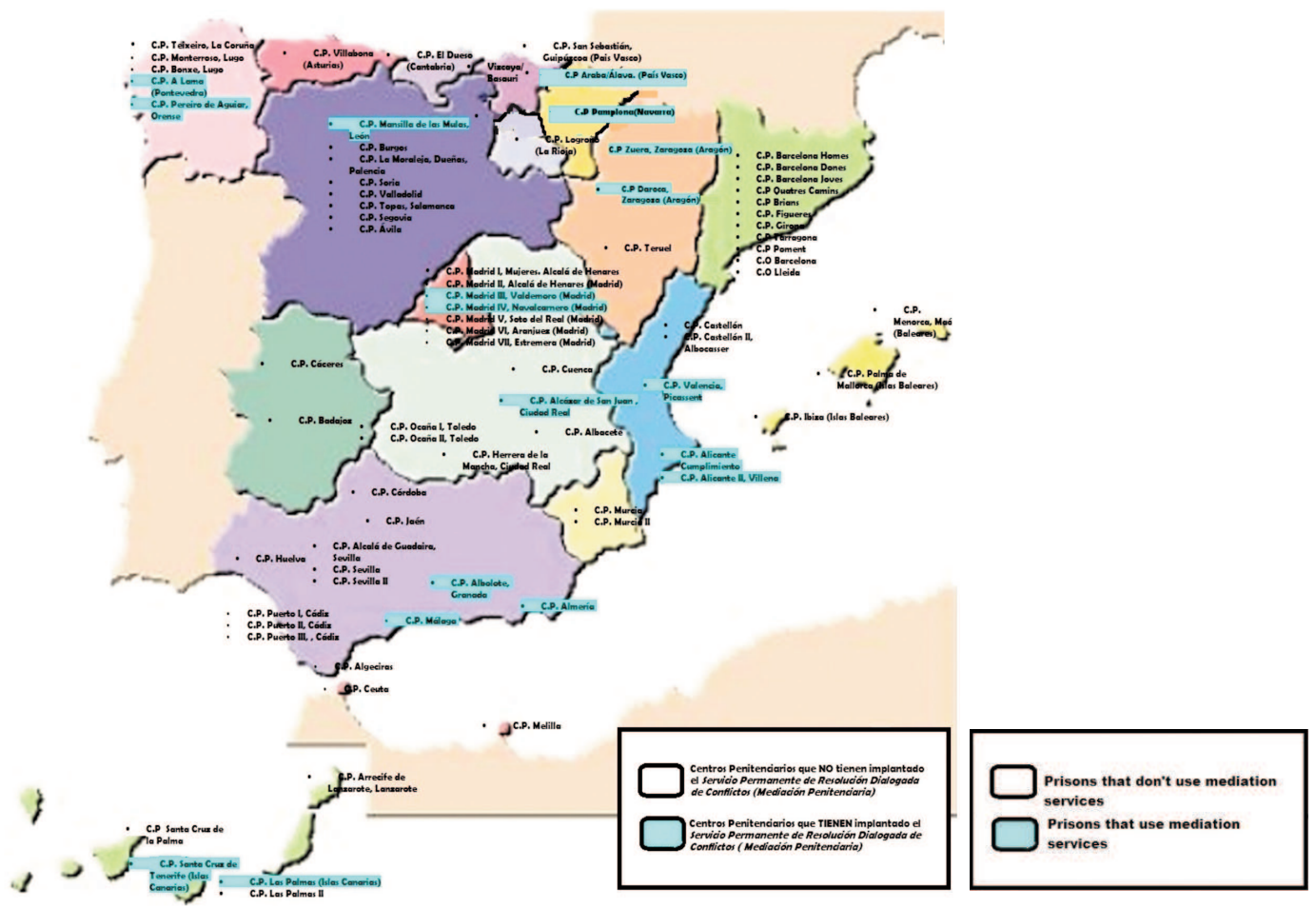

Fuente / Source: Elaboración propia / Authors. 
El servicio lo prestan tanto el personal penitenciario directamente como a través de ONG y departamentos universitarios, siendo principalmente los profesionales penitenciarios los que llevan a cabo el proyecto: "educadores con formación de mediación y resolución de conflictos".

Del análisis sistemático de la metodología utilizada podemos señalar que es la misma que en cualquier proceso de mediación, salvo algunas diferencias sobre todo en la fase de derivación. Existen tres procedimientos de derivación para acceder al servicio de mediación:

- Listado de incompatibilidades: entregado de forma regular por la Subdirección de Régimen y que suponen la continuidad del trabajo. La experiencia inicial de mediación en cada centro penitenciario debe hacerse con las personas catalogadas administrativamente de incompatibles por varios motivos: necesidad de acercamiento y conocimiento de los conflictos, conocimiento de la estructura y dinámica de funcionamiento del sistema, tiempo transcurrido desde el enfrentamiento, ensayo y adaptación de las técnicas mediadoras al ámbito penitenciario e inicio de confianza hacia los funcionarios.

- Instancias que los propios internos presentan al Director, en las que solicitan entrevista con los mediadores.

- Casos con expediente sancionador incoado: son expedientes facilitados por el Instructor referentes a conflictos surgidos con anterioridad, para los que se cuenta con un plazo en el que presentar los resultados de la mediación, previo a la reunión de la Comisión Disciplinaria que decide respecto al conflicto en cuestión.

De forma general, las fases de intervención son las siguientes: fase de derivación; fase de acogida e información; fase de aceptación y compromiso del proceso de mediación; encuentro dialogado/negociación y redacción y documentación de los acuerdos.

Para la caracterización de los servicios de mediación en los centros penitenciarios en España, presentaremos el resultado del análisis de las características por centro a partir de las entrevistas realizadas y las fuentes consultadas (Apromega, 2009; Fundación Affiniy, 2009; Alos et al., 2009; Asociación para la mediación de conflictos, 2006, 2007, 2008, 2009, 2010,
Systematic analysis of the methodology used can point to is the same as in any mediation process, except for some differences especially in the phase derivation. There are three ways to access the bypass mediation service:

- List of incompatibilities: delivered regularly by the Branch Board and assume the continuation of work. The initial experience of mediation in each prison should be done with people categorized administratively inconsistent for several reasons: the need for rapprochement and understanding of conflict, knowledge of the structure and operation of the system dynamics, time since the confrontation, testing and mediating adaptation techniques to prison environment and beginning of trust in officials.

- Instances that inmates themselves submitted to the Director, in which they request an interview with the mediators.

- Cases instituted disciplinary proceedings: records are provided by the instructor concerning disputes arising prior, for which there is a deadline by which to submit the results of mediation prior to the meeting of the Disciplinary Committee that decides on the conflict in question.

Generally, the intervention phases are: phase shunt, and information reception phase, phase acceptance and commitment to the mediation process; dialogued meeting / negotiating and drafting agreements and documentation.

To characterize mediation services in prisons in Spain, will present the results of the analysis of the characteristics of center from the interviews and the sources (Apromega, 2009; Foundation Affinity, 2009; Alos Et. Al, 2009, Association for convlict mediation, 2006, 2007, 2008, 2009, 2010, 2011; Association Talk, 2011, Secretary 
2011; Asociación ċhablamos?, 2011, Secretaria General De Instituciones Penitenciarias, 2011). Las dimensiones de análisis han sido: inicio del servicio, profesionales vinculados, horarios, tipo de gestión, metodología utilizada y resultados de las mediaciones. Como podremos identificar, la densidad de información es diferente en cada centro, puesto que no todos los centros han participado en la difusión de los datos.

- Centro Penitenciario Pereiro de Aguiar, Ourense (Galicia). Presta el servicio de mediación desde octubre de 2009 a través de la asociación APROMEGA (Asociación pro medicación Galicia). El programa consta de dos objetivos principales: crear habilidades para la gestión de conflictos y capacitación de pacificadores. Para su cumplimiento trabajan desde las emociones y los sentimientos, a través de dinámicas de grupo. Los destinatarios son los internos del módulo 4 (módulo de respeto).

- Centro Penitenciario Madrid III, Valdemoro (Madrid). Fue el primer centro que inicio el proyecto de mediación penitenciaría en España, concretamente en 2005. En el proyecto trabajan entre 4-6 profesionales, de ellos, al menos dos tienen además la especialidad de psicología. La intervención es de 3hs. /semana. En cuanto a los resultados, las mediaciones iniciadas han logrado un resultado positivo en el 50\% de los casos. Destacar que en muchos de los casos en los que no ha sido posible realizar la mediación, las causas son ajenas tanto a los mediadores como a los internos, en su mayor parte motivadas por traslados inesperados o dificultades idiomáticas. De las mediaciones iniciadas según los resultados se catalogan de la siguiente manera: acuerdo positivo con firma; acuerdo positivo sin firma (pacificación de las relaciones y reducción de la ansiedad de los internos, fin de la mediación de manera informal ya que no cumple con todos de los objetivos de la mediación); rechazo del proceso por una de las partes; interrupción del proceso (por circunstancias ajenas de los mediadores y de los internos); fin sin acuerdo; mediación no recomendable y demanda desajustada.

- Centro Penitenciario Madrid IV, Navalcarnero (Madrid). Utilizan los mismos protocolos que Madrid III, mediante una formación que estos dieron en octubre de 2007.
General of Prisons, 2011). The dimensions of analysis were: service startup, professionals involved, time, type of management, methodology and results of mediation. As we identify, the information density is different at each site, as not all centers participating in the dissemination of data.

- Prison Pereiro de Aguiar, Ourense (Galicia). Pay the mediation service from October 2009 through APROMEGA association (Association for medication Galicia). The program has two main objectives: to create skills for conflict management and training of peacekeepers. For compliance work from emotions and feelings through group dynamics. The recipients are internal module 4 Module (respect). - Penitentiary III Madrid, Valdemoro (Madrid). It was the first center to start the mediation project penitentiary in Spain, in 2005. The project work between 4-6 professionals, of which at least two are also the specialty of psychology. The intervention is 3hrs. / Week. As the results, have started mediations achieved positive result in $50 \%$ of cases. Note that in many cases where it was not possible to mediate, the causes lie beyond both the mediators and the inmates, mostly motivated by unexpected movements or language difficulties. Mediations initiated according to the results are graded as follows: positive agreement signed, unsigned positive agreement (pacification of relations and reducing anxiety of internal mediation to informally as not meet all the objectives of mediation); rejection process by a party; interruption of the process (through no fault of mediators and internal), end without agreement, mediation is not recommended and demand adjustment. - Madrid IV Prison, Navalcarnero (Madrid). They use the same protocols as Madrid III, through training that these occurred in October 2007.

- Compliance Alicante Penitentiary (C. Valenciana) use the mediation service since January 2011.

- Alicante Penitentiary II, Villena (C. Valenciana) They use mediation from January 2011 through training in Madrid CP III. 
- Centro Penitenciario Alicante Cumplimiento (C. Valenciana) Utilizan el servicio de mediación desde enero 2011.

- Centro Penitenciario Alicante II, Villena (C. Valenciana) Utilizan mediación desde enero de 2011 mediante una formación en el CP de Madrid III.

- Centro Penitenciario Valencia, Picassent. (C. Valenciana). Utilizan mediación desde enero de 2011 mediante una formación que el CP de Madrid III realizo en octubre de 2007.

- Centro Penitenciario Málaga, Alhaurin de la Torre (Andalucía) Utilizan el servio de mediación desde noviembre de 2005.

- Centro Penitenciario Mansilla de las Mulas, León (Castilla y León) Utilizan mediación desde octubre de 2007.

- Centro Penitenciario Alcázar de San Juan, Ciudad Real (Castilla la Mancha) Utilizan servicio de mediación desde 2010.

- Centro Penitenciario Zuera, Zaragoza (Aragón):

Servicio gestionado por la Asociación ¿Hablamos? de Zaragoza. A comienzos de 2006 se inicia el proyecto de mediación penitenciaria con la ayuda de la Red Nacional de Pacificación y mediación de conflictos. Las personas con las que se media son los internos incompatibles marcados por el propio centro penitenciario. En algunas ocasiones la Subdirección de Seguridad deriva conflictos de aquellas personas que todavía no han sido sancionadas por el sistema para que pueda realizarse la mediación antes de que la Comisión Disciplinaria adopte una resolución y así puedan valorar, a efectos sancionadores, la participación en el proceso de mediación y en su caso el resultado obtenido. Los internos que llegan a un acuerdo solicitan a la Dirección la eliminación de la incompatibilidad y reingresar al módulo de procedencia. De las mediaciones realizadas entre 2006 y 2010 los resultados son los siguientes: el $40 \%$ de las mediaciones no se ha iniciado, y de las mediaciones iniciadas el $33 \%$ llego a acuerdo y el $27 \%$ no alcanzaron acuerdo.

- Centro Penitenciario Daroca, Zaragoza (Aragón). El servicio de mediación lo gestiona la Asociación ¿Hablamos? En 2009 se presenta el proyecto de Gestión de Conflictos en el Módulo de Respeto y comienza a desarrollarse a comienzos del 2010. Este proyecto parte del modelo in-
- Prison Valencia, Picassent. (C. Valenciana). Use mediation from January 2011 through the formation of Madrid CP III conducted in October 2007.

- Prison Malaga, Alhaurin de la Torre (Andalusia) use the Serbian mediation since November 2005.

- Penitentiary Mansilla de las Mulas, Leon (Castilla y León) They use mediation since October 2007.

- Prison Alcazar de San Juan, Ciudad Real (Castilla la Mancha) utilizemediation service since 2010 They use mediation since 2010.

- Prison Zuera, Zaragoza (Aragon): Service operated by the Association talk? Zaragoza. In early 2006, the project began mediation prison with the help of the National Network for Peacebuilding and conflict mediation. The people who are internally inconsistent half marked by the prison itself. Sometimes the conflicts derived Security Branch of those who have not yet been sanctioned by the system, to permit mediation before the Disciplinary Commission adopt a resolution so they can assess, sanctioning purposes, participation in the process mediation and if the result obtained. Inmates agree Address request the removal of the incompatibility and reenter the source module. Mediations conducted between 2006 and 2010 results are as follows: $40 \%$ of mediations did not started, and mediations started to get 33\% agreement and $27 \%$ did not reach agreement.

- Prison Daroca, Zaragoza (Aragon). The mediation service is managed by the Association talk? In 2009 he introduced the draft Conflict Management in Module Respect and begins to develop in early 2010. This project is part of the integrated model for IES Juan Carlos Torrego of the Autonomous Community of Madrid. The service is comprised of five professionals, a technician and four volunteers from the Association. It addresses internal module 4, module with respect to establishing restorative justice mechanisms in conflict resolution processes Module Respect the Center for Conflict Resolution take that any

[ 214 ] ENRIQUE PASTOR SELLER Y ELENA HUERTAS PÉREZ 
tegrado de Juan Carlos Torrego para IES de la Comunidad Autónoma de Madrid. El servicio esta compuesto por 5 profesionales, un técnico y 4 voluntarios de la Asociación. Se dirige a internos del módulo 4, módulo de respeto con el objetivo de establecer mecanismos de Justicia restaurativa en los procesos de resolución de conflictos del Módulo de Respeto del Centro para llevar la resolución del conflicto que toda infracción supone a ámbitos de gestión relacionales e integradores. - Centro Penitenciario Araba/Álava, Nanclares de la Oca (País Vasco). El servicio de mediación se lleva a cabo desde 1998 a través de la Fundación Gizagune en Bilbao. Se trabaja con justicia restaurativa y resolución de conflictos en las comisiones de internos en los Módulos de respeto. Las funciones principales que desarrollan son: formación en gestión de conflictos a los internos; apoyo a las comisiones de convivencia en los módulos de respeto; intervención en el programa de Reparación del Daño y mediaciones. A lo largo del año 2011 se realizaron unas 25 intervenciones, sin contar con las intervenciones que realizan los propios internos, ya que para tal fin se les capacita consiguiendo una vertiente preventiva y reeducativa.

- Centro Penitenciario de Pamplona (Navarra) El servicio de mediación se desarrolla desde 2006 y es gestionado por la Asociación ANAME (Asociación de mediación de Navarra). Las mediaciones se realizan entre internos del módulo de hombre y mujeres. El equipo multidisciplinar esta compuesto por cinco abogados, criminólogos, dos psicólogas, todos ellos con formación en mediación. Las derivaciones al servicio se realizan por petición del interno, por el área de tratamiento y por el servicio jurídico penitenciario. En este centro no existen las incompatibilidades de internos. Desde que comenzó el servicio se han realizado 20 mediaciones, de las cuales una no ha llegado a acuerdo, 5 de ellas no se han podido realizar por traslado de los internos y el resto 14 han finalizado con acuerdo positivo. En 2008 se iniciaron unos talleres de resolución de conflictos (básico y avanzado) compuestos por 4 sesiones. Se ha intentado realizar formación de mediación a los funcionarios pero no ha dado resultado. En febrero de 2011 se iniciaron unos talleres llamados "teatro del oprimido" (BOAL, infringement is a relational management areas and integrators.

- Prison Araba / Álava, Nanclares de la Oca (Basque Country). The mediation service is carried out since 1998 by the Foundation in Bilbao Gizagune. We work with restorative justice and conflict resolution in internal commissions in respect Modules. The main functions that develop are: conflict management training to internal support coexistence commissions in respect modules; intervention program reparation and mediation. Throughout the year 2011 some 25 interventions were performed, without the interventions by the inmates themselves, because for this purpose are trained and getting a preventive arm reeducation.

- Prison Pamplona (Navarra) The mediation service is developed since 2006 and is managed by the Association ANAME (Navarra Mediation Association). Mediations are conducted inside the module between men and women. The multidisciplinary team consists of five lawyers, criminologists, two psychologists, all trained in mediation. Referrals to the service are made at the request of the inmate, the treatment area and the prison legal service. In this center there are no internal incompatibilities. Since the service began 20 mediations have been conducted, one of which has not reached agreement, five of them could not be done by transfer of inmates and the remaining 14 have been completed with positive agreement. In 2008 began a conflict resolution workshops (basic and advanced) composed of 4 sessions. Was attempted mediation training to officials but has not worked. In February 2011 began a series of workshops called "theater of the oppressed" (BOAL, 1979) in women modules, in which conflict resolution works implicitly, using drama to create a space of trust using interpretation tools.

An analysis of national survey we can conclude that although the increase of mediation has been accelerated both in its implementation and effectiveness, consider coverage remains inadequate and consolidation, being valued by pro- 
1979) en los módulos de mujeres, en los que se trabaja la resolución de conflictos implícitamente, utilizando el teatro para crear un espacio de confianza utilizando herramientas de interpretación.

Del análisis del estudio a nivel nacional podemos concluir que aunque el incremento de servicios de mediación ha sido acelerado tanto en su implantación como efectividad, consideramos aún insuficiente su cobertura y consolidación, siendo valorado por profesionales, profesores y entidades sociales como un método esencial para resolver los conflictos de manera pacífica en los Centros Penitenciarios.

\subsection{Análisis, desde sus participantes, de los con- flictos y la viabilidad de aplicación de la media- ción a partir del análisis de caso}

Con el fin de identificar, caracterizar y analizar la viabilidad de la aplicación de la mediación nos centraremos en el estudio de un caso, concretamente el Centro Penitenciario Murcia I con el fin de realizar un acercamiento cualitativo desde sus participantes (internos, profesionales y gestores) que nos permite disponer de la frecuencia de los conflictos, los métodos de resolución empleados, la opinión de la efectividad de las medidas, conocimiento de la mediación y la viabilidad de implantar el servicio de mediación y ante que conflictos sería posible, en base de datos recogidos mediante un cuestionario distribuido a los internos y profesionales del Centro.

La Región de Murcia tiene 1.470.069 habitantes de los cuales 1.593 (9,22\%) están condenados a estar en un Centro penitenciario. Concretamente el Centro Penitenciario de Murcia I, data de 1980 y se estructura de manera modular y cuenta con 340 celdas, ampliadas y modificadas en diversas ocasiones. Dispone de personal especializado (297) sujeto a régimen laboral y funcionarial y ha llegado a tener una población penitenciaria alrededor de 1200 internos, aunque en la actualidad cuenta con 445 internos, todos ellos de sexo masculino, divididos en 256 son internos preventivos y 189 internos penados.

Atendiendo al grupo de edad, el más representativo es el comprendido entre 31 a 40 años con 162 internos (37\%), seguido del grupo entre 41 a 60 años $(29 \%)$ y en porcentajes inferiores el grupo de 26 a 31 y 21 a 30 , con un 16\% cada uno de ellos. fessionals, teachers and social organizations as an essential method for solving conflicts in a peaceful manner in Prisons.

\subsection{Analysis from its participants, conflicts and feasibility of using mediation from case analysis}

In order to identify, characterize and analyze the feasibility of the application of mediation we will focus on a case study, namely the Murcia Penitentiary I in order to perform a qualitative approach from its participants (internal, professionals and managers) that allows us to have the frequency of conflict resolution methods employed, the opinion of the effectiveness of measures, knowledge of mediation and the feasibility of implementing the mediation service and before that would be possible conflicts in database collected through a questionnaire distributed to internal and Center professionals.

The Murcia region has 1,470,069 inhabitants, 1593 (9.22\%) are doomed to be in a prison. Specifically, the Prison Murcia I, dates from 1980 and is structured in a modular fashion and has 340 cells, expanded and modified several times. It has specialized staff (297) and subject to civil service and labor regime has come to have a prison population about 1,200 inmates, but currently has 445 inmates, all male, are internally divided into 256 and 189 preventive internal punished.

Considering the age group, the most representative is between 31 to 40 years with 162 inmates (37\%), followed by those between 41-60 years (29\%) and lower percentages group 26 to 31 and 21 to 30 , with $16 \%$ each.

In relation to the classification level of inmates, most of these are in the second level of

[ 216 ] ENRIQUE PASTOR SELLER Y ELENA HUERTAS PÉREZ 
En relación a el grado de clasificación de los internos, la mayoría de estos se encuentran en el segundo grado de clasificación 125 (66\%). A continuación registramos que 50 de los internos $(26,45 \%)$ se encuentran sin clasificar. En el tercer grado un 8 $(4,23 \%)$ de los internos con un régimen abierto. En el primer grado 5 internos $(2,64 \%$ ) y 1 se en grado excepcional (clasificación Art. 100.2 R.P).

Realizando un análisis de la historial criminal de los internos, es interesante constatar que más de la mitad son reincidentes (51\%), es decir ya han estado internados en un Centro penitenciario en ocasiones anteriores.

Respecto de las el dato más relevante es que 96 internos (52\%) están cumpliendo condenas de 6 meses a 3 años y 57 de los internos (31\%) cumplen condenas de 3 a 8 años. Con menores porcentajes podemos señalar las condenas de 8 años a 30 años. En resumen, la mayoría de los internos están cumpliendo condenas menores a 8 años.

$\mathrm{Si}$ analizamos los datos oficiales proporcionados por el Centro relativos a los diferentes tipos de delitos cometidos por las personas que están ingresadas observamos un dato relevante, a la par que significativo, que destaca sobre todos los demás: los delitos que atentan contra el patrimonio y el orden socioeconómico, en concreto los robos, presentan una notable visibilidad con un $31 \%$. El segundo dato que destaca sobre el resto son los delitos contra la salud pública con un $28 \%$, relacionado con el tráfico de drogas, en concreto con la adición de drogas y el recurso al comercio en pequeña escala para financiarse el propio consumo personal. Con menores porcentajes nos encontramos el delito de lesiones con un $7 \%$, el delito de agresiones sexuales con un $5,8 \%$, el delito contra relaciones familiares con un $5,2 \%$, el delito de homicidio con un $3,7 \%$, el de abusos sexuales con un $3 \%$ y por ultimo el robo y hurto de uso de vehículos con un $2,5 \%$. El resto de delitos se encuentra en menores cantidades con menos de 7 personas en cada delito.

La mediación es un método de resolución de conflictos entre internos, concretamente con internos catalogados como "incompatibles" ya sea por el propio Centro o por Instituciones penitenciarias y con internos con un expediente sancionador abierto, es decir que le les hayan sido puesta un sanción por alguna falta que hayan cometido en el centro. Pen- classification 125 (66\%). Then we recorded that 50 of the inmates $(26.45 \%)$ are not rated. In third grade an $8(4.23 \%)$ of inmates with an open regime. In grade 5 inmates (2.64\%) and one is in exceptional degree (Art. 100.2 RP classification).

If an analysis of the criminal history of offenders is interesting to note that more than half are repeat offenders (51\%), ie have been detained in a prison in the past.

With regard to the most relevant is that 96 inmates $(52 \%)$ are serving sentences of six months to three years and 57 inmates $(31 \%)$ are serving sentences of 3-8 years. With lower percentages can point sentences of 8 years to 30 years. In short, most of the inmates are serving sentences of less than 8 years.

If you look at the official data provided by the Centre regarding the different types of offenses committed by persons who are admitted observe a relevant data, at the same time significant, that stands out above all others: the crimes against heritage and socioeconomic order, namely theft, presents a remarkable 31\% visibility. The second piece that stands above the rest are the crimes against public health with $28 \%$, related to drug trafficking, particularly with the addition of the use of drugs and petty trade to finance their own personal consumption. With lower percentages found the offense of injury to $7 \%$, the crime of sexual assault at $5.8 \%$, the crime against family relationships with $5.2 \%$, the crime of murder with $3.7 \%$, the sexual abuse with $3 \%$ and finally the robbery and theft of vehicles using $2.5 \%$. All other offenses are found in smaller amounts with less than 7 people in each offense.

Mediation is a method of resolving disputes between inmates, inmates specifically listed as "incompatible" either by the center or correctional institutions and internal disciplinary proceedings open, meaning that they have been called one penalty who have committed some fault in the center. We think it is most important to note of Data Center and penalties under study.

According to data provided by the center today recognized nine internal incompatibilities, these are expected to solve A module with no possibility of resolving the conflict differently. 
samos que es de mayor importancia señalar datos de incompatibidades y sanciones del Centro objeto de estudio.

Según datos facilitados por el propio centro en la actualidad se reconocen 9 incompatibilidades entre internos, estas se prevén solucionar con un cambio de módulo sin posibilidad de solucionar el conflicto de otra forma. Por otro lado según los últimos datos se registraron 47 sanciones por el comportamiento de internos.

\subsubsection{Conflictos identificados por los participantes}

Al analizar los datos que nos ofrecen los cuestionarios se destaca que los conflictos que más se producen son los "conflictos entre internos" con un $93,6 \%$, seguidos de los "conflictos con insultos" con un $87,2 \%$, "los conflictos por robos" con un $82,1 \%$, en cuarto lugar se encuentran los conflictos con agresiones con $75,6 \%$ seguidos de los conflictos entre funcionarios e internos con un $61,5 \%$. Contamos con otros conflictos que los participantes contestaron libremente denominados "otros conflictos" con un $38,5 \%$, estos se encuentran detallados con posterioridad. Datos que nos ayudan a entender de ma-
On the other hand according to latest figures were 47 penalties for domestic behavior.

\subsubsection{Conflicts identified by participants}

In analyzing the data that we provide the questionnaires highlighted that most conflicts occur are the "internal conflicts" with $93.6 \%$, followed by "conflicts with insults" with $87.2 \%$, "conflicts by theft "with $82.1 \%$, fourth are conflicts with assault with $75.6 \%$ followed by conflicts between staff and inmates with $61.5 \%$. We have other conflicts that participants answered freely called "other conflicts" with $38.5 \%$, these are detailed later. Data to help us understand comprehensively the quantitative dimension of the conflicts in the middle.

Gráfico 2. Clasificación de conflictos

Figure 2. Classification of conflicts

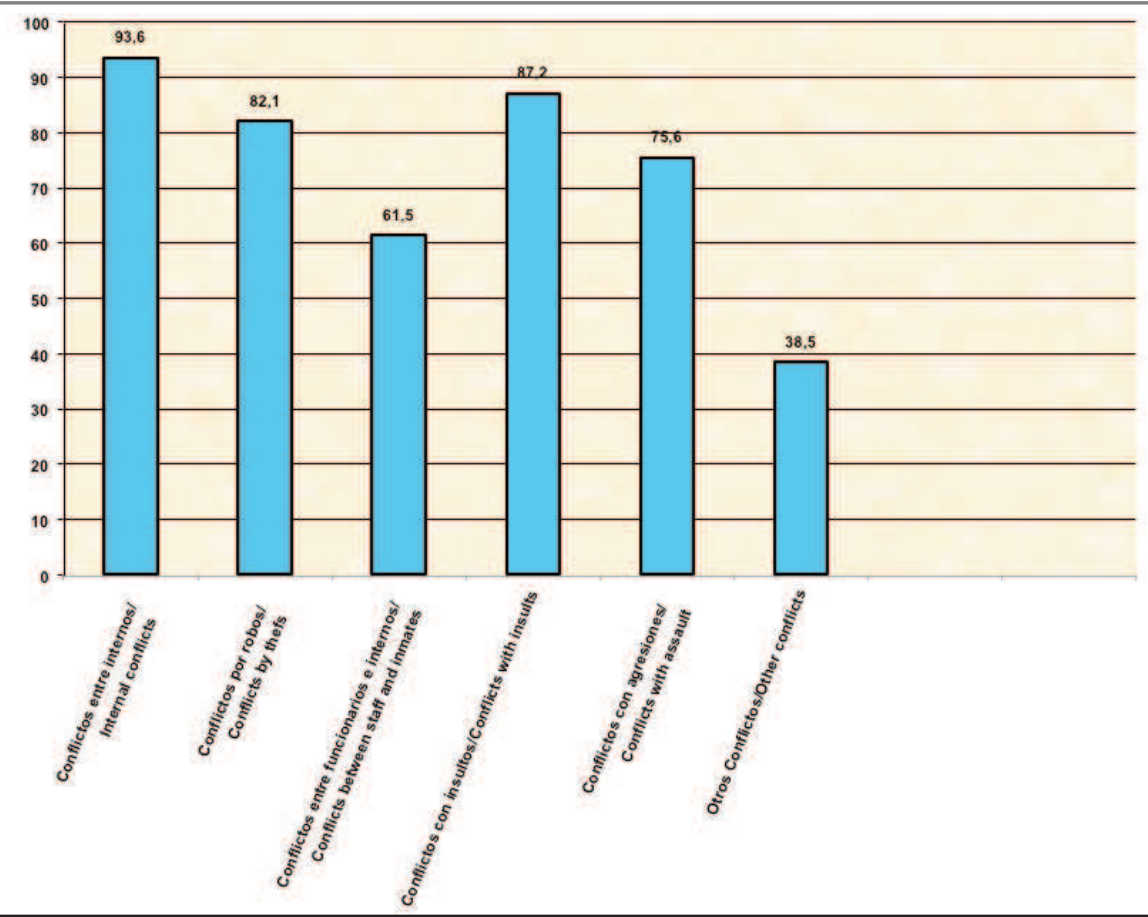

Fuente / Source: Elaboración propia a partir del análisis de datos del cuestionario / Authors.

[ 218 ] ENRIQUE PASTOR SELLER Y ELENA HUERTAS PÉREZ

SIPS - PEDAGOGIA SOCIAL. REVISTA INTERUNIVERSITARIA [1139-1723 (2014) 23, 199-229] TERCERA ÉPOCA 
nera global la dimensión cuantitativa de los conflictos en el centro.

\subsubsection{Frecuencia de los conflictos}

Analizando los tipos de conflictos de manera descendente, encontramos en primer lugar los conflictos entre internos representando el 93,59\%. En cuanto a la frecuencia el 32,05\% de los encuestados expone que se producen cada semana, el $24,36 \%$ señala que se ocasionan diariamente y en porcentajes menores responden que se producen mensualmente con un $15,38 \%$. El método de resolución más utilizado en conflictos entre internos es la evitación del conflicto $(23,08 \%)$ y la intervención judicial o administrativa (21,79\%), es decir poniendo sanciones. Un dato a destacar en cuanto al método de resolución es que el $16,67 \%$ de los encuestados responde que estos conflictos se solucionan ejerciendo la violencia. Algunos internos exponen "se solucionan con gritos y empujones" (E72)

Respecto a los conflictos que se producen con insultos representan el $87,18 \%$ de los casos. Curiosamente este tipo de conflictos se producen diariamente con el $26,92 \%$ y el $21,79 \%$ responden que se producen semanalmente, por lo tanto podemos señalar que los internos insultan en los conflictos con mucha frecuencia. Estos conflictos se soluciona con intervención judicial o administrativa $(24,36 \%$ ) y evitando el conflicto (19,23\%). Algunos internos exponen que este tipo de conflictos nunca se solucionan "según el insulto y según la persona, cuando el insulto es a un compañero se puede hablar, pero cuando es a la familia se puede ir de las manos" (E77)

Respecto a los robos se producen en el 83,3\%., "se escuchan robos ocasionalmente, a mi me robaron 6 paquetes de Winston que llevaba en la mochila (con ella colgada todo el día), yo me calle porque encima se ríen de ti, hay otros que se ponen a vocear en el patio, pero según lo que sea aparece raramente"(E18), "Puesto que muchos conflictos se ocurren por que no se estudian a los primerizos que entran en prisión los meten en módulos que hay mucha miseria y presos con la picardía les roban y les toman por tontos"(E77). Los robos ocurren semanalmente según los encuestados en el $24,36 \%$ de los casos, pero, además, el $21,79 \%$ de los participantes opinan que hay robos mensualmente y que esto ocasiona graves conflic-

\subsubsection{Frequency of conflicts}

Analyzing the types of conflicts in descending, we first find the internal conflicts between representing $93.59 \%$. As for the $32.05 \%$ rate of respondents states that occur every week, the $24.36 \%$ notes that are caused daily and respond in smaller percentages that occur monthly with a $15,38 \%$. The most widely used method of resolving conflicts between inmates is avoidance of conflict (23.08\%) and judicial or administrative action $(21.79 \%)$, ie putting sanctions. One thing to note about the method of resolution is that $16.67 \%$ of respondents replied that these conflicts are solved exerting violence. Some inmates exposed "are solved with shouting and shoving" (E Q 72)

With regard to the conflicts that occur with insults represent $87.18 \%$ of the cases. Interestingly such conflicts occur daily with $26.92 \%$ and $21.79 \%$ responded that occur weekly, therefore we can say that the insult in internal conflicts often. These conflicts are solved by judicial or administrative action (24.36\%) and avoiding conflict (19.23\%). Some residents argue that such conflicts are resolved never "as an insult and as a person, when the insult is a partner you can talk, but when the family can get out of hand" (E Q 77)

Regarding thefts occur in $83.3 \%$., "Thefts occasionally heard, I stole 6 packs of Winston that his backpack (with her hanging all day) above street because I laugh you, there are others who get to shout in the yard, but as it appears rarely "(E Q 18)," Since many conflicts occur that are not studied to first timers entering prison put them in modules are much misery and mischief prisoners to rob them and take them for fools " $E$ $Q$ 77). Robberies occur weekly as respondents in $24.36 \%$ of cases, but also the $21.79 \%$ of the participants say that is theft monthly and this causes serious conflicts in the middle. Usually resolved with administrative and judicial intervention (25.64\%). According to practitioners using surveillance and monitoring to find out who committed the robbery and then used the method to impose disciplinary sanctions. It has been noted that sometimes resorts to the mediation committee but is not common because there is no 
tos en el centro. Habitualmente se solucionan con la intervención judicial y administrativa (25,64\%). Según los profesionales se utiliza la vigilancia y el seguimiento para averiguar quien ha cometido el robo y seguidamente se utiliza el método disciplinario para imponer la sanción. Se ha señalado que en algunas ocasiones se recurre a la comisión de mediación pero no es lo habitual puesto que no hay un servicio permanente, algunos internos tienen formación en mediación pero no se utiliza. Exponen que raramente aparece lo que es robado, que a veces "algún interno delata al ladrón" (E40).

Los conflictos con agresiones surgen en el Centro, según los participantes, en un $76,92 \%$ de los casos y "los conflictos se dan según como este el patio" (E77). La mayoría de los casos no especifican la frecuencia de los conflictos, explican que no se puede concretar cada cuanto tiempo hay una agresión y el 19\% señala que mensualmente. La solución que más se utiliza en este tipo de conflictos es la intervención judicial y administrativa, con un parte disciplinario y aislamiento. Los profesionales de seguridad exponen que entre internos pueden acabar en violencia pero entre internos y funcionarios se aplica la fuerza mínima indispensable según reglamento. Según internos exponen los participantes "se solucionan con más violencia o represalias" (E72)

Los conflictos entre funcionarios e internos se producen en menor medida (62,82\%). La mayor parte de los entrevistados no contestan la frecuencia en la que suceden, sin embrago el $17,95 \%$ responde que se producen diariamente. En cuanto a la solución la más utilizada es la intervención judicial y un gran número de personas tampoco contestan a esta cuestión. Según comentarios de internos la solución mas utilizada "con la decisión del funcionario, con un parte y el cambio de módulo" (E22)

Por último, nos encontramos categoría "otros conflictos", un 38,83\% de los participantes informan que suceden otros conflictos no mencionados en categorías anteriores. El porcentaje menor ha sido para esta categoría, pero no por ello es menos importante, ya que a pesar de que el porcentaje sea bajo, ha sido una pregunta en la que hemos obtenido información muy útil a analizar, dado que permiten identificar desde los participantes otros conflictos. Así, según los participantes, en el Centro se producen conflictos causados por deudas y prestamos de di- permanent facility, some inmates are trained in mediation but not used. They state that rarely appears what is stolen, sometimes "some internal betrays the thief" (E Q 40).

Conflicts arise with the Center attacks, according to participants in a $76.92 \%$ of cases and "conflicts like this give according to the court" (E $Q$ 77). Most cases do not specify the frequency of conflict, explain that you can not realize how often there is aggression and $19 \%$ said that monthly. The solution that is used in this type of conflict is the judicial and administrative, disciplinary and an insulation part. Security professionals between internal state that can end in violence between inmates and officers but applies the minimum force necessary in accordance with regulations. According to expose internal participants "are solved with violence or reprisals" (E Q 72)

Conflicts between staff and inmates occur to a lesser extent (62.82\%). The majority of respondents did not answer the frequency in which they occur, no clutch the $17.95 \%$ answered that occur daily. As the most widely used solution is judicial intervention and a large number of people not answer this question. According to internal comments the most used "with the decision of the officer, with a hand and changing module" (E Q 22)

Finally, we find "other conflicts", a 38.83\% of participants' report that conflicts happen other than those listed in above categories. The percentage was lower for this category, but not least, because even though the percentage is low, it has been a question that we have obtained very useful information to analyze, since participants can identify from other conflicts. Thus, according to participants at the Centre are conflicts caused by debts and loans of money or objects that are made between the inmates themselves, as an intern says "leave money and then not give it back" (E Q 33). Conflict for profit or power in the group, "assaults, insults, intimidation, extortion, abuse of poor people are less to defend" (E Q 31), "some believe the masters of the court" (E Q 4). Since almost half of the inmates are foreigners occur "racism conflicts" (E Q 68). Finally, there are "medically conflicts" (E Q 56), ie by

[ 220 ] ENRIQUE PASTOR SELLER Y ELENA HUERTAS PÉREZ 
nero u objetos que se hacen entre los propios internos, como comenta un interno "dejas dinero y luego no te lo devuelven" (E33). Conflictos para conseguir beneficios o poder en el grupo, "agresiones, insultos, intimidación, extorsión, abusos de pobres que son menos para defenderse" (E31), "algunos se creen los amos del patio" (E4). Puesto que casi la mitad de los internos son extranjeros se producen "conflictos por racismo" (E68). Por ultimo, se producen "conflictos por motivos médicos" (E56), es decir, por la medicación y por "trapicheo de drogas" (E68), dato que se relación también con el tipo de delitos que hacen el ingreso en prisión, ya que como hemos comentado anteriormente, uno de los delitos más cometidos es contra la salud pública (trafico de drogas).

En cuanto a la frecuencia, el $60 \%$ no responde a la pregunta, aun así opinan que estos conflictos se producen semanalmente siendo el dato más representativo de las respuestas propuestas. El 14,10\% expone que este tipo de conflictos se solucionan mediante la intervención judicial o administrativa, destacando que el $60 \%$ de los participantes no ha contestado a esta cuestión.

A modo de conclusión y atendiendo a la frecuencia, los conflictos con insultos son los que más medication and by "drug dealing" (E Q 68), a fact that is also related to the type of crime that make the imprisonment, and which as we discussed earlier, one of the most committed crimes against public health is (drug trafficking).

In terms of frequency, $60 \%$ did not answer the question, still believe that these conflicts occur weekly data being the most representative of the proposed answers. The $14.10 \%$ states that such conflicts are resolved by judicial or administrative action, noting that $60 \%$ of respondents did not answer this question.

In conclusion and considering the often conflict with insults are the more they occur daily at a rate greater than the rest (26.92\%). Every week there are conflicts between inmates with a value that substantially exceeds the rest (32.5\%). Robberies occur monthly in the center with a higher percentage (21.79\%) if we relate with other conflicts, argues that although most robberies occur every week with a (24.36\%). Attacks occur monthly on the remaining highlighting conflicts significantly (19.2\%). The graph below shows the results of frequency conflicts regarding.

Gráfico 3. Frecuencia según conflictos (representados en \%)

Figure 3. Frequency as conflict (represented in \%)

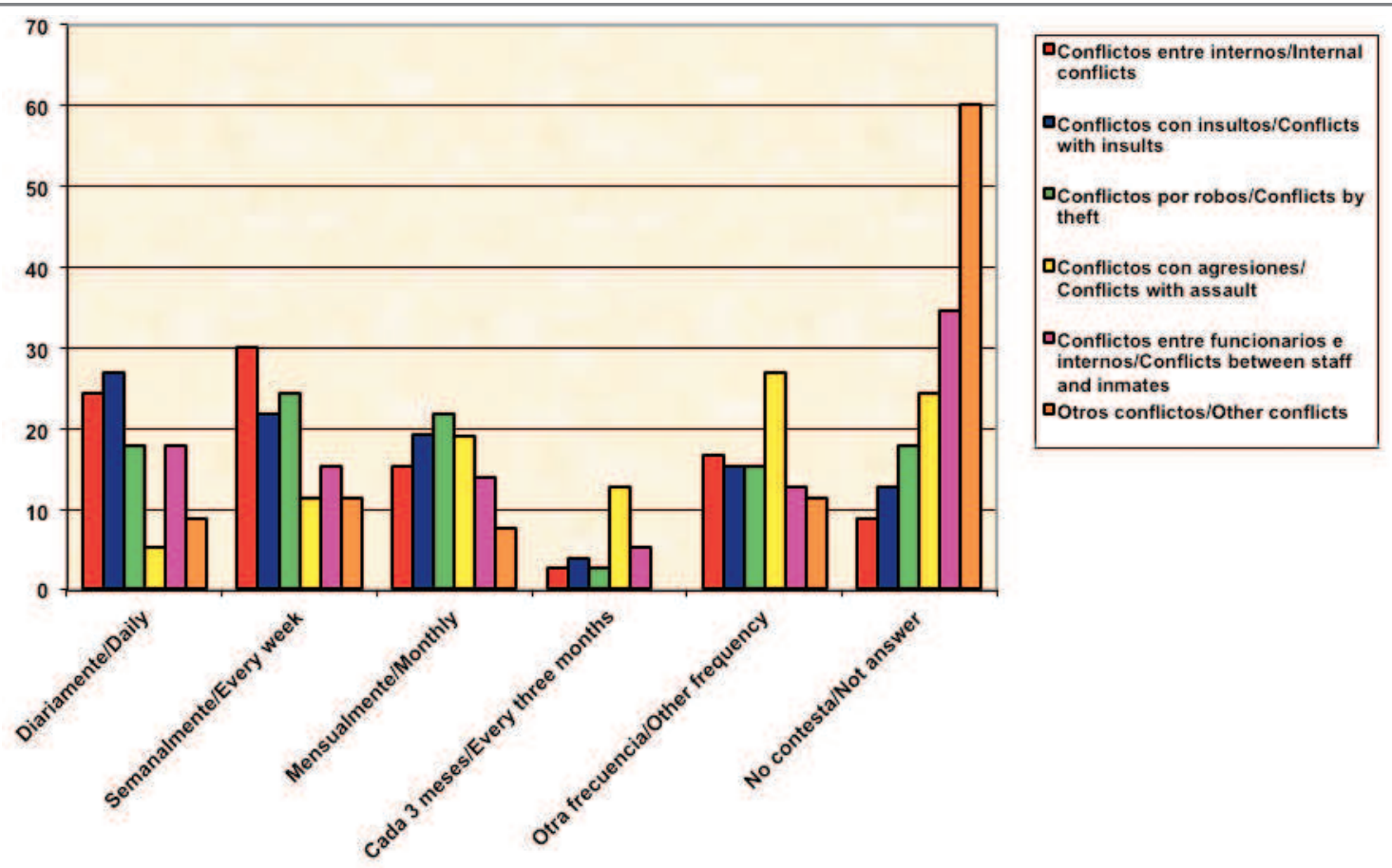

Fuente / Source: Elaboración propia / Authors. 
se dan al producirse diariamente con un porcentaje mayor al resto $(26,92 \%)$. Cada semana se producen conflictos entre internos con un valor que sobrepasa al resto considerablemente (32,5\%). Los robos se producen en el centro mensualmente con un porcentaje mayor $(21,79 \%)$ si lo relacionamos con el resto de conflictos, aunque la mayoría sostiene que se producen robos cada semana con un (24,36\%). Las agresiones se producen mensualmente destacando sobre el resto de conflictos de manera considerable (19,2\%). La siguiente gráfica expone los resultados de la frecuencia en relación los conflictos:

3.4.3. Forma utilizada para la resolución de conflictos vinculados con categorías de conflicto

La intervención judicial o administrativa, es decir la aplicación del régimen sancionador es el método de resolución de conflictos más utilizada dado que la mayoría de los conflictos tienen porcentajes superiores en este tipo de solución, concretamente en conflictos con agresiones y entre funcionarios e internos. Seguidamente los internos intentan solucionar el conflicto evitándolo, en especial en los conflictos entre internos y con insultos. Ejerciendo la violencia también tiene una representación consi-
3.4.3. Form used to resolve conflicts involving conflict categories

The judicial or administrative action in the application of the penalty system is the method most commonly used for conflict resolution since most conflicts have higher percentages in this type of solution, specifically aggression and conflicts between staff and inmates. Then the inmates try to solve the conflict by avoiding it, especially in internal conflicts and insults. Exerting violence also has considerable representation, especially in internal conflicts and robberies. With lower per-

Gráfico 4. Forma de resolución de conflictos según conflictos Figure 4. Resolve conflicts categories

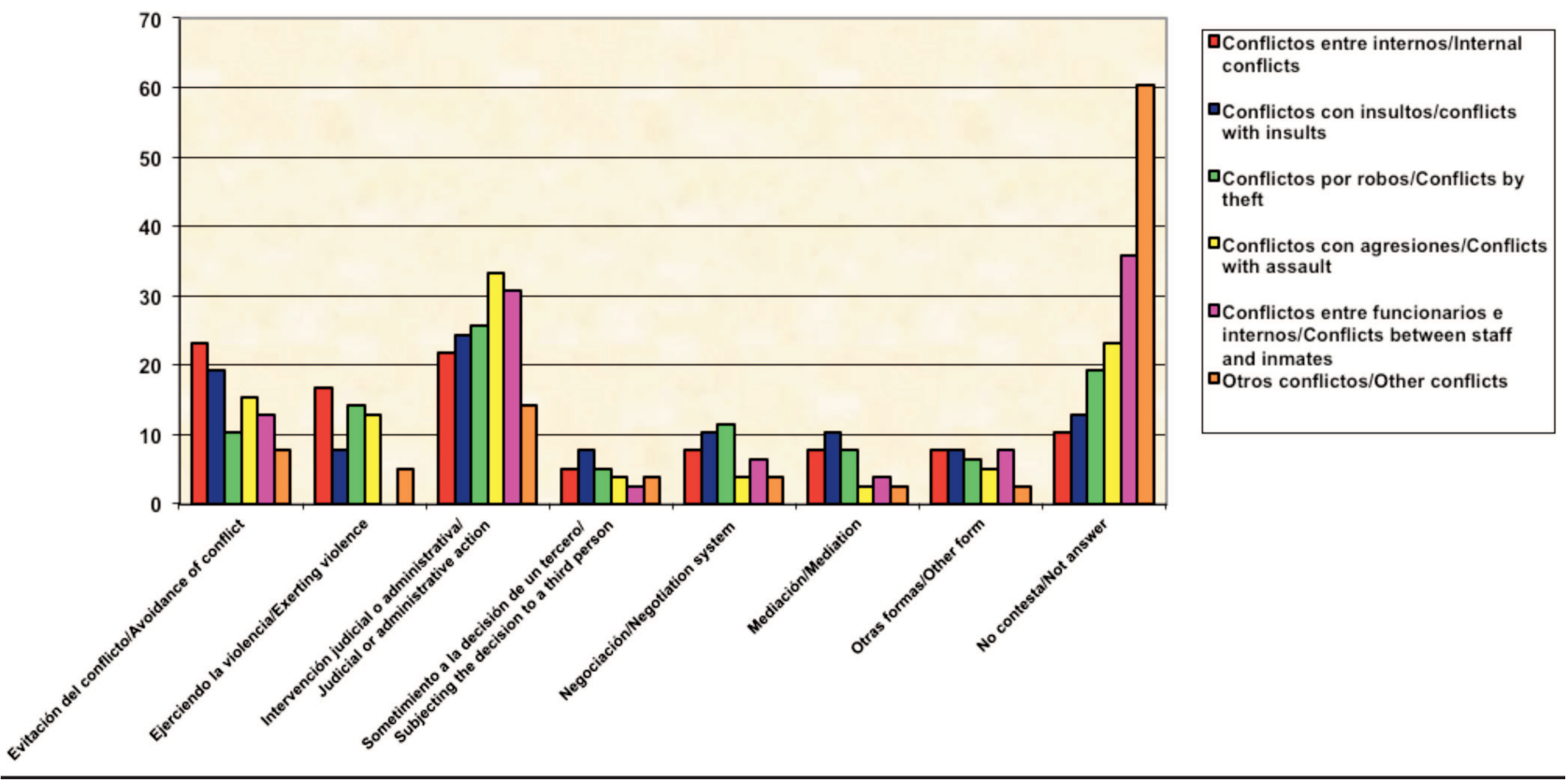

Fuente / Source: Elaboración propia / Authors.

[ 222 ] ENRIQUE PASTOR SELLER Y ELENA HUERTAS PÉREZ

SIPS - PEDAGOGIA SOCIAL. REVISTA INTERUNIVERSITARIA [1139-1723 (2014) 23, 199-229] TERCERA ÉPOCA 
derable, sobre todo en conflictos entre internos y por robos. Con porcentajes inferiores nos encontramos la negociación, el sometimiento a un tercero, la mediación y otras formas de solución, todos ellos representados en la siguiente gráfica:

3.4.4. Efectividad de las medidas utilizadas para solucionar los conflictos

El 73\% de las personas entrevistadas señalan que las medidas utilizadas son las adecuadas para solucionarlos y en menor medida informan que "todo es mejorable" (E50), ya que muchas de las medidas no solucionan los conflictos, exponen que "hace falta alguna medida conciliadora primando la utilización del dialogo" (E36). No obstante, otros profesionales justifican que las medidas son las adecuadas alegando que son las reglamentariamente impuestas avaladas legalmente. Por otra parte, el 65\% informan que estas medidas disminuyen los conflictos y por tanto reducen la reincidencia en los conflictos existentes, pero curiosamente la probabilidad de que se produzcan los conflictos es bastante elevada.

\subsubsection{Conocimiento de la mediación}

Un número elevado de personas conoce la mediación, concretamente el $43,59 \%$ de los participantes han definido correctamente la mediación. Entre los internos se encuentran personas que han estado en otros centros en los que se utiliza y su opinión es altamente positiva. La mayoría ha definido la mediación como un método para solucionar los conflictos pacíficamente, con respeto, utilizando el dialogo, con una persona neutral, la definen como: "un grupo de internos que se ocupan de dialogar con los internos que han tenido un conflicto y resolverlo sin que la causa trascienda" (E14), "en este centro no existe, supongo que se trata de llegar a un acuerdo entre dos partes" (E27), "se encarga de solucionar conflictos entre internos" (E25), "disciplina ocupada de prevenir y formar para tratar las situaciones en las que la convivencia provoca roces" (E43), "negociación de un tercero neutral" (E50), "proceso que trata de resolver conflictos pacíficamente" (E51), "solución pacifica de conflictos, responsabilización y equilibrio emocional" (E58), "poner paz y negociar los conflictos para solucionarlos" (E72), "medio de re- centages we are negotiating, submission to a third party, mediation and other forms of solution, all represented in the following graph:

3.4.4. Effectiveness of measures used to resolve conflicts

$73 \%$ of respondents indicated that the measures used are appropriate to solve and less report that "everything can be improved" (E Q 50), since many of the measures do not solve conflicts, state that "we need some measure prioritizing the use of conciliatory dialogue "(E Q 36). However, other professionals justify appropriate measures are claiming they are the statutorily imposed legally guaranteed. Moreover, 65\% report that these measures reduce conflicts and thus reduce recidivism in the conflicts, but curiously the probability of occurrence of conflicts is high.

\subsubsection{Knowledge of mediation}

A large number of people know mediation, namely $43.59 \%$ of participants correctly defined mediation. Among the inmates are people who have been to other resorts where it is used and your feedback is extremely positive. Most defined mediation as a method to resolve conflicts peacefully, respectfully, using dialogue, with a neutral, define it as: "a group of internal dialogue dealing with inmates who have had a conflict and solve without the cause transcends "( $(E$ Q 14)," in the center there, I guess it's come to an agreement between two parties "(E Q 27)," is responsible for solving internal conflicts "(E Q 25)," discipline be employed to prevent and to treat situations where coexistence causes friction "(E Q 43)," negotiation of a neutral third party "(E Q 50)," a process that seeks to resolve conflicts peacefully "(E Q 51)," Peaceful Settlement of Conflicts, accountability and emotional balance "(E Q 58)," make peace and negotiate to solve conflicts "( $(E$ Q 72)," means to resolve internal conflicts to resolve internal conflicts of interests “( $E$ Q 74). Although we have also identified 
solución de conflictos entre internos para resolver conflictos de intereses entre internos" (E74). Aunque también hemos identificado desconocimiento de la mediación, al concebirla como: aplicación del reglamento penitenciario, cambio de módulo al interno, utilización de castigos por parte de los funcionarios y evitar los conflictos, etc.

3.4.6. Viabilidad del servicio de mediación en el centro penitenciario

Los resultados de la investigación apuntan que un servicio de mediación sería necesario y aceptado en el Centro, ya que el 70,51\% de los participantes responden que seria altamente positivo. Relacionando este dato con el de conocimiento de la mediación, nos permite asegurar que los resultados son fiables. Para la mayoría (30,8\%) "todos los conflictos señalados" serian objeto de mediación y el 20,5\% indica que seria positivo utilizarla en "conflictos entre internos", si olvidarnos que el $22 \%$ no contesta a esta cuestión por mero desconocimiento. Estos resultados protagonizan el debate sobre la viabilidad de implantar un servicio de mediación en el Centro Penitenciario.

\section{Conclusiones}

La investigación nos informa que según el régimen sancionador, si un interno comete una falta se le aplica una sanción, normalmente de aislamiento y pérdida de beneficios. En los centros ocurren conflictos entre internos que no se resuelven y crean un ambiente contaminado y mala convivencia entre éstos. La aplicación del régimen disciplinario es un proceso que requiere un tiempo considerable, 3 meses como máximo hasta la resolución, si no se soluciona en estos meses queda sin solución. (Art. 246, RP 190/1996), por lo tanto es aconsejable que no sea el único método para solucionar conflictos en el medio penitenciario. Una de las finalidades de la aplicación del Reglamento Penitenciario es la estimulación de la responsabilidad, pero en la mayoría de los casos fomenta irresponsabilidad, ya que se aplica una sanción sin relación ninguna a la falta y el arrepentimiento de las partes es mínimo y no reconocido. Se considera que no es un proceso constructivo, ya que las partes no producen un aprendizaje significativo. Por otra parte lack of mediation, to think of it as: application of prison rules, change the internal module, use of punishment by officials and avoid conflicts, etc..

\subsubsection{Feasibility mediation service in the prison}

The research results indicate that a mediation service would be required and accepted at the Center, as the $70.51 \%$ of the participants responded that it would be highly positive. Linking this data with the knowledge of mediation, we can ensure that the results are reliable. For most (30.8\%) "All identified conflicts" would be subject to mediation and $20.5 \%$ indicated it would be good to use in "internal conflicts", if you forget that $22 \%$ did not answer this question by simply ignorance. These results star in the debate on the feasibility of implementing a mediation service in the prison.

\section{Conclusions}

Research tells us that as the penalty system, if an offender commits a foul a penalty is applied, usually of isolation and loss of benefits. In centers internal conflicts occur that are not resolved and create a polluted environment and poor living among them. The application of the disciplinary system is a process that requires considerable time, 3 months until resolution, if not addressed in these months remains unresolved. (Art. 246, RP 190/1996), therefore it should not be the only method to resolve conflicts in prisons. One of the purposes of the application of the Prison Rules is the stimulation of the responsibility, but in most cases encouraged irresponsibility, because penalty is applied without regard to any lack and repentance of the parties is minimal and unrecognized. It is considered that there is a constructive process, as the parties do not produce meaningful learning. Furthermore, and although the Regulation does not mention mediation it is

[ 224 ] ENRIQUE PASTOR SELLER Y ELENA HUERTAS PÉREZ 
y aunque el Reglamento no menciona la mediación cabe la posibilidad de revocar sanciones o anular incompatibilidades si la mediación obtiene un acuerdo positivo. Se considera complementaria la aplicación de la mediación para solucionar conflictos, facilita la comunicación, potencia la responsabilidad, acepta la diversidad y el conflicto es percibido como una oportunidad no como una amenaza, facilitando una mejor convivencia en el centro.

Hemos podido comprobar que España cuenta con una de las tasas más elevadas de población reclusa de Europa (71.565). La mayoría provienen de ambientes marginales, con bajo nivel educativo, pocas habilidades sociales, escasos recursos económicos, escaso apoyo familiar. El 92\% son hombres y el grupo de edad más representativo es de personas de 31 a 40 años con un $34,60 \%$. Los delitos más cometidos en el caso de los hombres son delitos por robo y en el caso de las mujeres delitos de tráfico de drogas.

Se puede concluir que a nivel estatal, la aplicación de la mediación penitenciaria es muy reciente (2005) siendo 18 los centros penitenciarios (22,5\%) que utilizan la mediación para resolver los conflictos mediante un programa específico llamado "Resolución permanente dialogada de conflictos". Este servicio se presta normalmente mediante asociaciones que trabajan en la materia y departamentos universitarios. Los conflictos mas habituales son "conflictos entre internos". En España la mediación penitenciaria es muy reciente pero con resultados notables según los resultados de varios servicios, ya que el $50 \%$ de las mediaciones iniciadas finalizan con un acuerdo positivo y es importante destacar que los servicios de mediación que se implantan son evaluados favorablemente por lo que continúan por los benéficos que estos aportan.

En el análisis de caso se constata que la mediación podría ser un camino para el aprendizaje de valores útiles, destacando la responsabilización de estos en sus actos, para no ver el sistema penitenciario como un mero castigador de conductas, sino una posibilidad de cambio para no repetir éstas y viable jurídicamente. Entre la tipología de conflictos destaca los conflictos entre internos, con insultos, por robos, con agresiones, entre funcionarios e internos, por motivo de drogas, conflictos por préstamos y deudas, por temas de medicación, por racismo y conflictos por obtención de beneficios (permisos) y po- possible incompatibilities revoke or cancel penalties if mediation yields a positive agreement. It considers complementary application of mediation to resolve conflicts, facilitates communication, power, responsibility, acceptance of diversity and conflict is seen as an opportunity rather than a threat, providing a better living in the center.

We have seen that Spain has one of the highest rates of prison population in Europe $(71,565)$. Most come from marginal environments, with low education, poor social skills, low income, poor family support. 92\% were men and the age group is more representative of people from 31 to 40 years with a $34.60 \%$. The more crimes committed in the case of men are crimes of theft and in the case of women drug trafficking offenses.

It can be concluded that statewide implementation of penal mediation is very recent (2005) being 18 prisons (22.5\%) who use mediation to resolve conflicts through a special program called "permanent resolution of conflicts through dialogue ". This service is usually provided by associations working in the field and university departments. The most common conflicts are "internal conflicts". Mediation in Spain is very recent prison but with remarkable results according to the results of various services, since $50 \%$ of mediations end with an agreement initiated positive and it is important to note that mediation services are evaluated favorably implanted at by continuing beneficial they bring.

In the case study finds that mediation could be a way for learning useful values, emphasizing the accountability of those in their actions, not to see the prison system as merely punishing behavior, but a possibility of change for not repeat these and legally feasible. Among the types of conflicts between internal stresses conflict, with insults, robberies, with assaults, between staff and inmates, because of drugs, conflict and loan debts, medication issues, racism and conflicts for profit ( permits) and power in the group. Without any doubt the application of the penalty system is the method most commonly used conflict resolution in the center, justified by its legal value, hence the desirability of identifying the need to give legal cover to mediation in prisons. 
der en el grupo. Sin ningún género a dudas la aplicación del régimen sancionador es el método de resolución de conflictos más utilizado en el centro, justificada por su valor legal, de ahí la conveniencia de identificar la necesidad de dar cobertura legal a la mediación en el ámbito penitenciario. Otro método de resolución muy utilizado es la evitación del conflicto; consideran que es muy apropiado y por lo tanto nos hacen reflexionar sobre la importancia de formación de resolución de conflictos, ya que la evitación del conflicto no lo soluciona. Se dispone de un conocimiento alto del significado de la mediación. Los datos muestran que una gran mayoría opinan que las medidas que se utilizan en el centro son las adecuadas e incluso reducen los conflictos, ahora bien, lo que contrasta con el elevado número y frecuencia de los conflictos. Es muy interesante constatar que la mediación es altamente aceptada (70,5\%), pero, además, cabe señalar que el 100\% de los entrevistados que conocen la mediación consideran que sería positivo utilizarla en el centro. Otro dato a tener presente, es el tipo de conflictos que pueden solucionarse mediante la mediación, ya que desde las primeras lecturas se tenía presente la pregunta ¿Qué conflictos son objeto de mediación? En relación a los datos obtenidos, para la mayoría todos los conflictos señalados son objeto de mediación y consideran útil la aplicación de un servicio de mediación en el centro. La mediación es, por consiguiente, conocida y aceptada en el centro, lo que unido al número y frecuencia elevada de conflictos induce a afirmar la viabilidad de implantación de un servicio de mediación para la resolución pacifica de conflictos en el centro penitenciario, así como talleres formativos para ampliar el conocimiento de de la gestión de conflictos. Dichos resultados son coherentes con el análisis de los beneficios y oportunidades que ofrece la mediación en los centros penitenciarios en los que lleva un tiempo implantada.

\section{Alternativas y propuestas}

La investigación realizada nos brinda alternativas y propuestas concretas de acción orientadas a impulsar métodos alternos de resolución de conflictos entre internos, así como las potencialidades que ofrece su implantación en los centros atendiendo a la experiencia en los que se encuentra implantado.
Another widely used method is the resolution of conflict avoidance; consider it very appropriate and therefore make us reflect on the importance of conflict resolution training as conflict avoidance does not help. It has a high knowledge of the meaning of mediation. The data show that a large majority believe that the measures used in the center are appropriate and even reduce conflicts, however, in contrast to the high number and frequency of conflicts. It is very interesting to note that mediation is highly accepted (70.5\%), but also should be noted that $100 \%$ of respondents who know the positive mediation would consider using it in the center. Another point to keep in mind is the type of conflicts that can be resolved through mediation, since from the first readings had this question: What conflicts are the subject of mediation? Regarding the data, for most all conflicts listed are subject to mediation and helpful should consider a mediation service in the center. Mediation is therefore known and accepted in the center, which together with the number and frequency of conflict induces high affirm the feasibility of implementing a mediation service for the peaceful resolution of conflicts in the prison, and workshops training to develop expertise in conflict management. These results are consistent with the analysis of the benefits and opportunities offered mediation in prisons in which it takes a while implanted.

\section{Alternatives and proposals}

The research gives us alternatives and concrete proposals for action aimed at promoting alternative means of resolving internal conflicts and the potential offered by its implementation in the light of the experience centers in which is implanted. 
La implantación de la mediación penitenciaria en el Centro Penitenciario Murcia I requiere introducir la mediación en el Reglamento Penitenciario lo que le dotaría de un respaldo legal, facilitando y legitimando su implementación. Para una adecuada implantación es imprescindible que los funcionarios e internos desarrollen un proceso de formación acerca de los mecanismos alternativos de resolución de conflictos (MARC), específicamente respecto de la mediación; debiendo asegurarse los medios necesarios para su adecuada cumplimiento e impulsar acuerdos de cooperación con organizaciones sociales que puedan contribuir a su adecuado desarrollo atendiendo a las experiencias acumuladas.

Por otra parte, es conveniente continuar incidiendo en acciones de sensibilización y concienciación social y de los centros sobre las potencialidades de la mediación en el entorno penitenciario, mostrando los beneficios de dicho proceso para los internos y los profesionales; intensificando la coordinación entre profesionales de asociaciones de mediación y los centros penitenciarios. Es oportuno introducir la mediación en el Reglamento Penitenciario con el objetivo de darle cobertura legal para su efectivo cumplimiento.

Continuar trabajando en la implantación, consolidación y ampliación, según los casos, de servicios de mediación en los Centros Penitenciarios Españoles. Concretamente en el estudio de caso estudiado se demuestra su viabilidad como método para solucionar conflictos.

Es necesario desarrollar talleres formativos de gestión dialogada de conflictos, con el objetivo de conocer que es un conflicto, las oportunidades que ocasiona y métodos de resolución para internos y profesionales.

Por último, es muy importante disponer de informes anuales por centros respecto de los servicios de mediación con el fin de visibilizar resultados y proyectar/transferir en ámbitos penitenciarios.
The implementation of mediation in the prison Murcia I require to enter mediation in the Prison Rules what would give a legal backing, facilitating and legitimizing its implementation. For proper implementation is vital that staff develop a process and internal training on alternative mechanisms for dispute resolution (ADR), specifically regarding the mediation must ensure the means necessary for proper compliance and boost cooperation agreements with social organizations that can contribute to their proper development taking into account the experiences gained.

Moreover, it is appropriate to continue influencing awareness and social awareness and centers on the potential of mediation in the prison setting, showing the benefits of this process for internal and professionals, enhance coordination between professional associations mediation and prisons. It is appropriate to introduce mediation in the Prison Rules in order to give legal cover for their effective implementation.

Continue working on the implementation, consolidation and expansion, as appropriate, mediation services in Spanish prisons. Specifically in the case study demonstrates the feasibility study as a method of conflict resolution.

It is necessary to develop management training workshops conflict through dialogue, in order to know that it is a conflict, causes and opportunities for internal resolution methods and professional.

Finally, it is very important to have annual reports on centers mediation services in order to visualize results and project / transfer in correctional settings.

\section{Notas}

${ }^{1}$ Art. 188.4 RP 190/1996: las disposiciones de Régimen disciplinario contenidas en este reglamento no eran de aplicación a los pacientes internados en estas instituciones. 


\section{Bibliografía / References}

Álvaro Cáliz, J. (2007). La falacia de más policías, más penas y más cárceles: el problema de la inseguridad y el castigo desde una visión alternativa. Nueva sociedad, 208, 40-55.

Azaola, E. y Bergman, M. (2007). De mal en peor: las condiciones de vida en las cárceles mexicanas. Nueva sociedad, 208, 118-127.

APROMEGA. Asociación Pro Mediación en Galicia. (2009). Programa de resolución de conflictos en prisión. Galicia. Roneo.

Asociación ċhablamos? (2011). Programa de Intervención de Mediación Penitenciaria. Zaragoza: Centro Penitenciario Daroca, Roneo.

Asociación de Mediación para la Pacificación de Conflictos (2006). Memoria Mediación Penitenciaria. Madrid: Centro Penitenciario Madrid III, Valdemoro, Roneo.

Asociación de Mediación para la Pacificación de Conflictos (2007). Memoria Mediación Penitenciaria. Madrid: Centro Penitenciario Madrid III, Valdemoro, Roneo.

Asociación de Mediación para la Pacificación de Conflictos (2008). Memoria Mediación Penitenciaria. Madrid: Centro Penitenciario Madrid III, Valdemoro, Roneo.

Asociación de Mediación para la Pacificación de Conflictos. (2009). Memoria Mediación Penitenciaria. Madrid: Centro Penitenciario Madrid III, Valdemoro, Roneo.

Asociación de Mediación para la Pacificación de Conflictos. (2010). Memoria Mediación Penitenciaria. Madrid: Centro Penitenciario Madrid III, Valdemoro, Roneo.

Asociación de Mediación para la Pacificación de Conflictos. (2011). Memoria Mediación Penitenciaria. Madrid: Centro Penitenciario Madrid III, Valdemoro, Roneo.

Boal. A. (1979). Theatre of the Oppressed. London.

Cea D’Ancona, M. A. (1978). Metodología cuantitativa. Estrategias y técnicas de investigación Social. Madrid: Síntesis.

Alos, R., Martín, A. y Gilbert, F. (2009). ¿Sirve el trabajo penitenciario para la reinserción?, Un estudio a partir de las opiniones de los presos de la cárcel de Cataluña. Revista Española de Investigaciones Sociológicas,127, 11-31.

Denzin, N. K.(1975). The research act. A theoretical introduction to sociological methods. New York: McGraw Hill.

Foucalt, M. (1990). Vigilar y castigar, Madrid: Siglo XXI.

FUNDACION AFFINITY (2009). Programa de Terapia Asistida con animales en el Centro Penitenciario Alicante II. [Documental televisivo]. Alicante: Televisión Española.

Lauroba, E. (2011). Le point de la mediation en Espagne. European Association of Judges for mediation. Retrieved from .

Marcuello-Servos, C. y García-Martínez, J. (2011). La Cárcel como espacio de Socialización ciudadana: ¿Fracaso del sistema Penitenciario Español?. Revista Portularia, XI, 1, 49-60.

Perello, S. (2010). Metodología de la investigación. Dykinson S.L.

Rios, J.C. (2001). Manual de ejecución penitenciaria, defenderse en la cárcel. Madrid: Colex, S.A.

Rios, J.C. (2008). La mediación penal y penitenciaria, Experiencias de diálogo en el sistema penal para la reducción de la violencia y el sufrimiento humano. Madrid: Colex, S. A.

Rios, J. C., Pascual, E. y Bibiano, A. (2005). La mediación penitenciaria, reducir violencias en el sistema carcelario. Madrid: Colex, S.A.

Secretaria General de Instituciones Penitenciarias (2011). El Sistema Penitenciario Español Taller de Artes Gráficas de Madrid III. Roneo.

[ 228 ] ENRIQUE PASTOR SELLER Y ELENA HUERTAS PÉREZ

SIPS - PEDAGOGIA SOCIAL. REVISTA INTERUNIVERSITARIA [1139-1723 (2014) 23, 199-229] TERCERA ÉPOCA 


\section{CÓMO CITAR ESTE ARTÍCULO / HOW TO CITE THE ARTICLE}

Pastor Seller, E. y Huertas Pérez, E. (2014). Mediación penitenciaria, una alternativa a la resolución pacífica de conflictos entre internos. Pedagogía Social. Revista Interuniversitaria, 23 199-229. DOI:10.7179/PSRI_2014.23.09

Pastor Seller, E. \& Huertas Pérez, E. (2014). Prison mediation as alternative dispute resolution between domestic prisons. Pedagogia Social. Revista Interuniversitaria, 23 199-229. DOI:10.7179/ PSRI_2014.23.8

Fecha de recepción del artículo / received date: 12.v.2013

Fecha de revisión del artículo / reviewed date: 17.IX.2013

Fecha de aceptación final / accepted date: 30.1X.2013

\section{DIRECCIÓN DEL AUTOR/ AUTHOR' ADDRESSES}

Enrique Pastor Seller, Elena Huertas Pérez. Universidad de Murcia. Facultad de Trabajo Social. Campus Espinardo, s/n 30100 Espinardo, Murcia. España.

Correo electrónico / e-mail: epastor@um.es

\section{PERFIL ACADÉMICO / ACADEMIC PROFILE}

Enrique Pastor Seller. Profesor Titular de Universidad. Actualmente es Decano de la Facultad de Trabajo Social de la Universidad de Murcia. Es Investigador Principal del Grupo de Investigación Trabajo Social y Servicios Sociales. Cuenta con Sexenios acreditados de Investigación.

Elena Huertas Pérez. Graduada en Trabajo Social por la Universidad de Murcia y Máster en Mediación e Intervención Social por la misma Universidad. 